\title{
PARTY STRENGTH AND ECONOMIC GROWTH
}

\author{
By FERNANDO BIZZARRO, JOHN GERRING, \\ CARL HENRIK KNUTSEN, ALLEN HICKEN, \\ MICHAEL BERNHARD, SVEND-ERIK SKAANING, \\ MICHAEL COPPEDGE, and STAFFAN I. LINDBERG*
}

1 ANY agree that political institutions matter for economic growth, search has centered on regime types, ${ }^{2}$ property rights and the rule of law, ${ }^{3}$ bureaucracy and the developmental state, ${ }^{4}$ and overall state capacity. ${ }^{5}$ In this article, we focus on political parties, which, we argue, influence economic development independent of other institutions. ${ }^{6}$

A large literature extending back to the birth of modern political

* This research project was supported by Riksbankens Jubileumsfond Grant M13-0559:1, PI: Staffan I. Lindberg, V-Dem Institute, University of Gothenburg, Sweden; Knut and Alice Wallenberg Foundation to Wallenberg Academy Fellow Staffan I. Lindberg, Grant 2013.0166, V-Dem Institute, University of Gothenburg, Sweden; Research Council Norway, Young Research Talent Grant 240505, PI: Carl Henrik Knutsen; and the National Science Foundation Grant SEs-1423882, "Collaborative Research: Institutions and Development: A Disaggregated, Historical Analysis"; as well as by internal grants from the Vice Chancellor's Office, the Dean of the College of Social Sciences, and the Department of Political Science at University of Gothenburg; and the Kellogg Institute for International Studies and the Department of Political Science at the University of Notre Dame. We performed simulations and other computational tasks using resources provided by the Swedish National Infrastructure for Computing (SNIC) at the National Supercomputer Center in Sweden, SNIC 2016/1-382 and 2017/1-68, and by the Center for Research Computing (CRC) at the University of Notre Dame. We specifically acknowledge the assistance of In-Saeng Suh at CRC and Johan Raber at SNIC in facilitating our use of their respective systems. We thank seminar participants at the V-Dem Institute, the Kellogg Institute for International Studies, and the 2015 meetings of the American Political Science Association and the European Political Science Association, as well as the anonymous reviewers and the editors of World Politics for their insightful comments.

Replication data for this article are available at Bizzarro et al. 2018a.

${ }^{1}$ Bardhan 2005.

${ }^{2}$ Acemoglu et al. 2014; Gerring et al. 2005.

${ }^{3}$ Acemoglu, Johnson, and Robinson 2001; Haggard and Tiede 2011; Knack and Keefer 1995; North 1990.

${ }^{4}$ Evans and Rauch 1999; Kohli 2004; Leftwich 1995; Wade 1990; Woo-Cumings 1999; Amsden 1992.

${ }^{5}$ Bockstette, Chanda, and Putterman 2002; Fukuyama 2011; Huntington 1968.

${ }^{6}$ Although there is some empirical overlap between our measure of party strength and other measures of "good institutions," the correlations are modest (see Section II). In any case, we take care to control for these alternate theories in our empirical tests (see Sections IV-V).

World Politics, 70, no. 2 (April 2018), 275-320

Copyright (C) 2018 Trustees of Princeton University

doi: $10.1017 /$ S0043887117000375 
science attests to the importance of political parties in establishing conditions for democratic stability and accountability. ${ }^{7}$ More recently, scholars have demonstrated the capacity of strong parties to resist clientelism and provide public goods, functions that presumably enhance economic performance. ${ }^{8}$ Meanwhile, a distinct literature on autocratic regimes finds that institutionalized parties help to stabilize authoritarian rule. ${ }^{9}$ Researchers have also noted that one-party regimes are associated with greater investment and stronger growth performance than what is achieved by other types of autocracies. ${ }^{10}$

The literature on political parties thus suggests that the strength of political parties may matter for economic performance in both democratic and autocratic contexts, though parties may play somewhat different roles under different types of regimes. Notably, multiparty elections create interparty competition that affects how parties behave. But the impact of parties on economic growth may depend not only on interparty dynamics, but also on intraparty dynamics. Specifically, the way in which parties are organized affects their ability to govern the economy. ${ }^{11}$ Sweden, a strong-party regime within a democratic context, is different from Papua New Guinea, where parties are small, weak, evanescent, and subordinate to individual politicians, just as China, where all power is centralized in the Communist Party, is different from Saudi Arabia, a partyless monarchy.

Following this reasoning, we argue that the internal organization of political parties affects long-term development in both democratic and authoritarian contexts. This is not to deny that some mechanisms differ across regime contexts, but rather to assert that some mechanisms operate similarly in democracies and autocracies. The argument we forward thus bridges two traditions of work on political parties-one focused on democracies and the other on autocracies - and combines it

\footnotetext{
${ }^{7}$ Bryce 1896; Mainwaring and Scully 1995; Ranney 1954; Wilson [1908] 2001.

${ }^{8}$ Hicken, Kollman, and Simmons 2016; Kitschelt and Wilkinson 2007; Simmons 2016; Simmons et al. 2017; Tommasi 2006.

${ }^{9}$ Boix and Svolik 2013; Brownlee 2007; Greene 2007; Huntington 1968; Magaloni 2006; Magaloni 2008; Magaloni and Kricheli 2010; Svolik 2012.

${ }^{10}$ Gandhi 2008; Gehlbach and Keefer 2011; Gehlbach and Keefer 2012; Keefer 2007; Miller 2015; Wright 2008.

${ }^{11}$ Work on parties in democracies usually focused on the "external dimension" of party system institutionalization, i.e., patterns of interparty competition. Our conceptualization of party strength leans toward the "internal dimension" of party system institutionalization, i.e., party organizational structures and party rootedness in society (Coppedge 1997; Hicken and Kuhonta 2015; Levitsky 2003; Mainwaring and Scully 1995; Mainwaring, Bizzarro, and Petrova 2018; Powell and Tucker 2014; Randall and Svåsand 2002). The literature on autocratic parties, naturally, focuses mainly on the latter (e.g., Brownlee 2007; Geddes 2005; Gehlbach and Keefer 2011; Magaloni 2006; Svolik 2012), with some attention to linkages between opposition party actors and the ruling party (e.g., Gandhi 2008).
} 
with important insights from previous work on institutions and development. Our theory thus integrates diverse strands from multiple literatures to make a cohesive case for the role of political parties in economic development.

Before continuing, we offer two important caveats. First, our argument does not presuppose that other institutional features are inconsequential. Growth is a complex outcome in which many institutional and noninstitutional factors presumably play a role. Second, our theory does not imply that stronger parties always lead to higher growth. There may be situations in which strong parties mitigate growth, for example, if parties adopt ideologies that incline them to pursue growthretarding policies, such as expropriation of private capital or the suppression of market-based pricing. Nonetheless, our theory predicts, ceteris paribus and in a probabilistic fashion, that stronger parties lead to higher economic growth

To test the theory, we draw on a unique data set from the Varieties of Democracy (V-Dem) project. ${ }^{12}$ Based on coding by thousands of country experts and covering most sovereign and semi-sovereign states over the past century, V-Dem provides indicators focused on different features of political parties, which we employ to construct a composite index of party strength. Using this index, we conduct myriad tests to probe the relationship between political parties and economic growth. Estimators include ordinary least squares (OLS) with country and year fixed effects, generalized method of moments, and instrumental variables. A unique feature of the V-Dem data is the ability to incorporate measurement error into a causal model, which we deploy in an additional robustness test. Another key feature of the V-Dem data is the inclusion of measures of several distinct institutional features that may influence growth, such as property rights protection, corruption, and features of the state administration. We highlight that the relationship between party strength and growth is robust to controlling for such alternative institutional features and that the relationship appears in quite different contexts, including democracies and autocracies.

In Section I, we present our argument about how and why party strength affects economic growth. In Section II, we describe our data and the construction of the index of party strength. In Section III, we explore country cases in East and Southeast Asia, which provide an illustration of the index and our argument. In Section IV, we estimate the impact of party strength on growth in a global sample. In Section

${ }^{12}$ Coppedge et al. 2017a. 
$\mathrm{V}$, the relationship is subjected to a series of specification tests. In Section VI, we explore the impact of party strength on other outcomes of relevance, including economic stability. In Section VII, we review the argument and discuss its ramifications.

\section{THEORY}

Insofar as political institutions - including political parties - matter for economic performance, their influence is likely to be indirect rather than direct. The pathway from institutions to growth involves multiple interconnected causal mechanisms. Our explanatory framework recognizes three intervening steps that connect the character of party organizations with economic performance, illustrated in Figure 1. In brief, the organizational features of parties shape the incentives and capabilities of politicians, which in turn affect the selection of policies; this generates responses by workers, investors, entrepreneurs, and other economic actors, which influence both short- and long-term growth performance. We review each stage while acknowledging that they are not always neatly demarcated in time and are sometimes characterized by feedback loops. ${ }^{13}$

\section{Party Organization}

The institutional factor of theoretical interest is the strength of political parties in a polity, understood to include all major parties (considered together). Strong parties are defined as those that are unified, centralized, stable, organizationally complex, and tied to long-standing constituencies.

Where these traits are lacking, parties are weak or perhaps entirely absent. In such settings, other forms of political organization, such as personalist rule, ${ }^{14}$ group-based rule (where ethnic, racial, religious, or economic groups form the basis of power),${ }^{15}$ or military rule, ${ }^{16}$ are likely to predominate. Of course, the extent to which political parties or these

\footnotetext{
${ }^{13}$ We do not aim to theorize the underlying sources of party strength. Extant work on this topic is largely context-specific - focused on particular countries, regions, types of parties, or historical eras (see, e.g., Chiocchetti 2016; David 1972; LeBas 2011; Tavits 2012). This literature suggests that historical junctures like revolutions, wars, anticolonial struggles, suffrage extensions, and the establishment of parliamentary sovereignty played a key role in some countries, while in others the development of parties was a more gradual affair (Rokkan and Lipset 1967; Hicken and Kuhonta 2015; Levitsky et al. 2016). If such country-specific historical junctures also shape economic development patterns, cross-country correlations between party strength and growth would yield biased estimates of a possible effect. This is a key reason why we include country fixed effects in our regressions.

${ }^{14}$ Jackson and Rosberg 1982.

${ }^{15}$ Wimmer 2013.

${ }^{16}$ Finer 2002; Huntington 1957.
} 


\begin{tabular}{|ccccc|}
\hline I. $\longrightarrow$ II. $\longrightarrow$ III. $\longrightarrow$ IV. $\longrightarrow$ V. \\
$\begin{array}{c}\text { Party } \\
\text { organization } \\
\text { capabilities }\end{array}$ & Policies & $\begin{array}{c}\text { Responses } \\
\text { by economic } \\
\text { actors }\end{array}$ & Growth \\
\hline
\end{tabular}

FIGURE 1

The Argument Summarized

alternatives hold sway is a matter of degree. Nonetheless, it is important to understand the full range of variation implied by the concept of party strength.

Several features of our definition deserve further discussion. One key feature of a strong party is an established national organization in which influence is formally distributed by position (rather than person), decision-making procedures are formalized and regularized through clear rules and statutes, and appointment decisions follow formal procedures. By streamlining decision-making processes and enabling collective decisions, these features allow strong parties to ensure cohesion and unity while responding to broad national constituencies. They also help to centralize decision-making power within the party organization rather than dispersing it among disparate politicians or alternatively, to locate it in the hands of a single individual, the hallmark of personal rule. For example, Vietnam's ruling Communist Party has institutionalized a degree of checks and balances by distributing power among a "diffused Troika" of leaders - namely, the president, the prime minister, and the party general secretary. ${ }^{17}$ In addition, strong-party organizations develop specialized apparatuses for handling tasks including election campaigning, collecting donations, developing policy, and monitoring (and subsequently rewarding or punishing) party members inside and outside parliament.

Strong parties display organizational complexity by maintaining branches throughout the territory. Regional and local party branches are important for eliciting information about the preferences of citizens and the situation on the ground. This intelligence is especially important in autocracies, where trusted sources of information are scarce and where local party cadres are relied upon to give early warning of potential discontent or sources of opposition. Local branches are also important for carrying out election campaigns (which, even in an authoritarian context, provide important signals of party control)

${ }^{17}$ Malesky, Abrami, and Zheng 2011. 
and enrolling new members. In this fashion, strong parties create direct links to broad masses of citizens without relying solely on patronage networks.

\section{INCENTIVES AND CAPABILITIES}

The organizational features of a strong party affect the incentives and capabilities of leaders in three ways. They establish a relationship of accountability between party leaders and party members, encourage long time horizons, and enhance the party's capacity to solve coordination problems.

\section{ACCOUNTABILITY}

First, where parties are strong, leaders' ambitions should be constrained to fulfill the ambitions of the party, not only their personal goals. As John Gerring and Strom Thacker propose, a strong party "synchronizes individual career goals with the party's quest for political power." 18 Constraints on leaders stem partly from the process of leadership selection, which in a strong party favors individuals with a demonstrated commitment to the party. Organization men and women, thoroughly socialized in the party, are likely to emerge from a party-centered selection process. ${ }^{19}$ It is not likely that a leader would be able to deviate from the party line, even if that leader so desired. Strong parties provide checks against wayward leaders, employing internal mechanisms of control that are often informal. ${ }^{20}$ Cases as diverse as Kosovo, El Salvador, Bosnia, and Mozambique have demonstrated that such parties have strong intraparty competition "mechanisms for regulating the relationships between party leaders, for selecting candidates, and for determining party electoral strategy." 21

In democracies, party activists and officials may resist actions by the executive if such actions conflict with their interests and the long-term interests of the party. ${ }^{22}$ In autocracies, a tightly organized party structure in which members are in continual contact with one another and have long-standing personal relationships may allow party members to overcome collective action problems and serve as an effective counterweight to the top leadership. ${ }^{23}$

\footnotetext{
${ }^{18}$ Gerring and Thacker 2008, 36-37.

${ }^{19}$ Carreras 2012.

${ }^{20}$ Panebianco 1988; Gehlbach and Keefer 2011; Gehlbach and Keefer 2012; Svolik 2012.

${ }^{21}$ Manning 2007.

${ }^{22}$ Stokes 1999.

${ }^{23}$ Svolik 2012.
} 
For these reasons, we expect a modicum of accountability to operate within a strong party even when there are no formal institutions mandating anything that may be described as intraparty democracy. One empirical indication of this accountability-generating capacity is the ability of strong parties to limit the tenure of rulers and, in some cases to control the leadership selection process in autocratic settings, such as Vietnam (after Ho Chi Minh), China (after Mao), the USSR (after Stalin), and Mexico (under the PRI). Strong political parties thereby provide credible checks on executive power in much the same way as is claimed for formal, constitutional constraints. ${ }^{24}$

\section{TIME HORIZONS}

Strong parties with established organizations and formalized appointment and decision-making procedures are likely to be enduring. ${ }^{25} \mathrm{Be}-$ cause of this longevity, leaders and others whose interests are aligned with a party's fate are more likely to approach policy-making with a long-term perspective. There is evidence that a party's image and overall support among the citizenry is colored by the policies and overall performance achieved during periods when the party ruled. Legacies matter, so parties that expect to stick around have an incentive to work for long-term benefits while imposing short-term costs. ${ }^{26}$

The long time horizons and knowledge that other strong parties in the system are likely to endure also open opportunities for comprehensive bargains between parties. One illustrative example is the ongoing Norwegian pension reform, which started in early 2001 and is scheduled to be completed and implemented in 2025. Although different phases of the reform were initiated under different governments, a core feature is the legislative decision of 2005 under which all major political parties, except the Socialist Left Party and the right-populist Progress Party, formalized their agreement on the main principles. Key content of the reform includes increasing the retirement age and reducing expected pension benefits for certain groups. These changes come with short-term costs for important constituencies, but they are intended to increase labor supply, to keep pension costs under control, and to enhance long-term growth. ${ }^{27}$ For rival parties to lay aside political disagreements and forego opportunities for short-term political gains that

\footnotetext{
${ }^{24}$ Acemoglu, Johnson, and Robinson 2001; Besley and Kudamatsu 2008; North and Weingast 1989; Wright 2008.

${ }^{25}$ Panebianco 1988.

${ }^{26}$ Hankla 2006; Pitcher 2012; Simmons 2016.

${ }^{27}$ Holmøy and Stensnes 2008.
} 
abstaining from the bargain may present is no small feat, and such a drawn-out process with anticipated long-term gains would arguably be difficult to conduct in political systems with weak parties operating on a short time horizon.

\section{COORDINATION}

In addition to longevity, the organizational tools that strong parties wield should ease coordination among party members. Party organizations provide fora for striking bargains, meaning that individual politicians, each with different interests and constituencies, may agree to support undesired policies in one area as long as their interests are supported by the party in other areas. Strong party organizations also provide the tools for monitoring individual party members-candidates and parliamentarians - and for rewarding good behavior or enforcing penalties if members stray from the party line. ${ }^{28}$ Beatriz Magaloni shows how in an autocratic setting party organizations use side payments, perks, and opportunities for advancement to strengthen politicians' incentives to invest in the party. ${ }^{29}$ Accordingly, strong parties should be characterized by cohesion, at least with respect to major policy initiatives (where discipline is essential), and minimal opportunistic party switching (where elected members of a party change their party affiliation between elections). These attributes could be especially important for legislative stability and accountability in democracies, where legislatures often operate more independently from the executive and play a more important role in policy-making.

As national organizations that represent various geographic areas and social groups, strong parties are also more capable of linking broad and varied constituencies throughout the country. This allows party leaders to strike deals that involve intertemporal tradeoffs and to enforce those deals through time. ${ }^{30}$ Similarly, programmatic linkages should increase coordination and thus facilitate collective action. ${ }^{31}$

\section{POLICIES}

The incentives and capabilities that strong parties create have important implications for the policies party leaders select and for how those policies are implemented.

${ }^{28}$ Malesky and Schuler 2011.

${ }^{29}$ Magaloni 2008.

${ }^{30}$ Boix and Svolik 2013; Hicken 2016; Hicken and Simmons 2008; Kuhonta 2011; Magaloni 2006; McGillivray 1997; Müller 2000; Nielson 2003; Svolik 2012; Tommasi 2006.

${ }^{31}$ Hanson 2010. 
First, constraints placed on leaders by strong parties suggest that predatory policies will be restrained. ${ }^{32}$ Social groups owning capital or land are likely to have a voice in at least one major party, and this should establish incentives for that party to discourage predatory policies, including expropriation and other infringements on private property rights. ${ }^{33}$ The longer time horizons imposed by strong parties should also incentivize leaders to protect property rights. ${ }^{34}$ Constraints on rulers and longer time horizons also may mitigate other kinds of predatory policies, for example hyperinflationary monetary policies or very high export tax rates. ${ }^{35}$

Second, strong parties are more likely to prioritize productivityenhancing public goods and services benefitting the wider population. Examples include infrastructure and education and health services. ${ }^{36}$ Philip Keefer and Cesi Cruz argue that parties whose internal organization reduces free riding by members and shirking by leaders encourage policymakers to care more about the broad consequences of their decisions. ${ }^{37}$ For example, in Brazil and Thailand shifts from party systems characterized by extremely weak parties to systems with stronger, national parties corresponded to the adoption of nationally oriented social welfare policies in the form of the Bolsa Familia in Brazil and the 30-baht health care scheme in Thailand. ${ }^{38}$ These programs produced improvements in public health, and such progress is empirically associated with stronger economic growth. ${ }^{39}$

Third, governments led by strong parties should be more capable of reaching authoritative decisions on contested matters of public policy, overcoming the opposition of entrenched institutions and economic interests and making decisions stick. This is essential to the adoption of efficiency-enhancing reforms that impose costs on specific constituencies. Under authoritarian rule in Mexico before 1987, for example, the official PRI monitored and enforced compliance with the policies of the president and his handpicked cabinet. Party-affiliated organizations routinely co-opted or marginalized bureaucrats at any level,

${ }^{32}$ Besley and Kudamatsu 2008.

${ }^{33}$ Ansell and Samuels 2014.

${ }^{34}$ Knutsen 2011a; Olson 1993.

${ }^{35}$ Knutsen 2013.

${ }^{36}$ Hicken, Kollman, and Simmons 2016.

${ }^{37}$ Keefer 2013; Cruz and Keefer 2015. Moreover, distributing private goods to supporters is a relatively cheap way of ensuring loyalty for politicians with very narrow constituencies, such as in many personalist or military regimes. But this is expensive when leaders try to cater to different constituencies, as will often be the case in countries led by strong parties, inducing politicians to instead prioritize public goods spending. See Bueno de Mesquita et al. 2003.

${ }^{38}$ Hicken and Selway 2012; Diaz-Cayeros, Estévez, and Magaloni 2016.

${ }^{39}$ Well 2007. 
including teachers, police, judges, military officers, professional associations, union officials, or peasant leaders who openly dared to challenge the official line. ${ }^{40}$

Fourth, strong parties are well-positioned to help facilitate effective implementation, once policies - including routine ones needed for investment and growth, such as tax collection and enforcement of property rights, in which there is often a gap between formal rules and informal practice - are approved. The state-centered literature highlights how a meritocratically recruited, rule-following civil service is key to effective implementation ${ }^{41}$ and has positive effects on growth. ${ }^{42}$ Yet a strong party may also help improve implementation through different mechanisms. As discussed above, regional party branches and stable linkages with citizen groups help strong parties to elicit information about appropriate policy design for legislation and to find policies that are adapted to local contexts, which eases the subsequent task of effective implementation. ${ }^{43}$ Further, a coherent political party should improve monitoring and control of civil servants, making sure that they are responsive to policy cues from the top. ${ }^{44}$ Together, these capacities should help to establish credible commitment for policies, even in the absence of formal constitutional constraints. ${ }^{45}$

\section{Responses by Economic Actors}

Insofar as economic policies are different in weak- and strong-party regimes, economic and societal actors face different sets of incentives in these contexts. Their responses matter for both short- and long-term economic growth.

First, the absence of predatory policies and the presence of credible commitment to growth-sustaining policies generate a stable economic environment that reduces uncertainty and increases expected incomes, which, in turn, induce investment. ${ }^{46}$ Critical in such cases is investment in research and development, which should lead to enhanced productivity over time. Channeling resources into innovation has higher expected profits when, for instance, property rights are protected. ${ }^{47}$ Public

${ }^{40}$ Magaloni 2006, 44-55.

${ }^{41}$ Evans 1989; Woo-Cummings 1999.

${ }^{42}$ E.g., Evans and Rauch 1999.

${ }^{43}$ Strong parties may also be better at processing information and inferring the effectiveness of government policies from election results, especially in democracies, but also in electoral authoritarian regimes; Miller 2015.

${ }^{44}$ See Gulzar and Pasquale 2017.

${ }^{45}$ Gehlbach and Keefer 2011.

${ }^{46}$ Alesina et al. 1996; Rodrik 1991.

${ }^{47}$ E.g., North 1990; Romer 1993; Acemoglu 2009. 
investments in infrastructure-a type of public good that strong parties are expected to provide - reduce transaction costs and are thus conducive to higher levels of private investment and innovation. ${ }^{48}$

Second, broad-based health and education policies should also have positive effects on economic productivity by virtue of lowering transaction costs and improving human capital. ${ }^{49}$ Higher levels of human capital also could enhance firms' incentives to innovate and adopt productivity-enhancing technologies. ${ }^{50}$

Third, polities ruled by strong parties should be less susceptible to civil war and political instability more generally. ${ }^{51}$ This environment also should enhance investment and overall productivity.

\section{GROWTH}

Although the impact of the foregoing factors on growth may seem selfevident, it is important to sketch out the causal pathways in more detail to clarify implications for short- and long-term growth. We have argued that governance by strong parties influences economic actors to increase supply in the major input categories identified by economic growth theory. Neoclassical theories of growth suggest that increased investment in physical and human capital increases growth in the short to medium term. ${ }^{52}$ Likewise, sound monetary and fiscal policies should help avoid short-term economic crises, and the avoidance of civil war and other elements of instability should reap positive short-term consequences for growth. ${ }^{53}$ For all these reasons, we expect party strength to enhance short-term growth.

Lagged and even very long-term effects may also be realized. ${ }^{54} \mathrm{With}$ respect to education policies, for example, positive effects on growth materialize when the relevant cohort of children grows up and enters

${ }^{48}$ E.g., Murphy et al. 1989.

${ }^{49}$ Mankiw, Romer, and Weil 1992.

${ }^{50}$ Lucas 1988; Kremer 1993.

${ }^{51}$ Fjelde 2010; Bernhard et al. 2015.

${ }^{52}$ Solow 1956; Mankiw, Romer, and Weil 1992. Strong parties are also likely to enhance input accumulation and static efficiency gains, which affect short-term growth through channels other than those discussed above, for example, through enacting comprehensive regulatory reforms pertaining to the labor market or tax system. Such reforms affect investments as well as the incentive of workers to supply more labor or to reallocate efforts to more productive sectors and tasks.

${ }^{53}$ Gates et al. 2012.

${ }^{54} \mathrm{We}$ note that some policies that may increase productivity and even growth in the longer term, for example, comprehensive reforms to labor markets or international trade, may be associated with short-term hardships and lower growth as the economy transitions. Insofar as strong parties enhance long-term growth through enabling the pursuit of such comprehensive reforms, it may contribute to mitigating the positive effect of party strength on short-term growth. Although this may be critical in certain contexts, such as the postcommunist transition economies right after the end of the Cold War, we find it improbable that such contractionary effects, in most contexts, should dominate all the other channels through which party strength enhances short-term growth. 
the workforce. ${ }^{55}$ Insofar as party strength enhances innovation and adoption of new technologies, its impact on growth is likely to persist over time. ${ }^{56}$ Indeed, Joel Simmons finds that durable parties with presumed longer time horizons are more likely to make the switch from factor accumulation to long-term growth and support investment in innovation and technological upgrading. ${ }^{57}$

\section{Party Strength}

Party strength, as defined above, refers to the unity, centralization, organizational complexity, and mass constituency of a party. To operationalize this concept, we employ six indicators from the V-Dem data set. These measure the extent to which political parties within a polity are characterized by (1) permanent national party organizations, (2) permanent local party branches, (3) centralized mechanisms of candidate selection, (4) legislative cohesion, (5) minimal party switching, and (6) programmatic, rather than clientelistic, linkages to their social base. See Table A1 in the supplementary material for exact question wording, clarifications, and response categories. ${ }^{58}$

Together, these indicators measure both the scope of party strength within a country (by asking about how many of the parties for national office have permanent and professional national organizations or local branches) and the degree to which they meet certain characteristics associated with strong parties (cohesive, programmatic, centralized, and in control of their elites).

$\mathrm{V}$-Dem indicators, including the six party strength indicators listed above, result from an aggregation of answers provided by thousands of experts worldwide to a series of categorical questions designed to capture relevant dimensions of political regimes and institutions. Experts are recruited on the basis of their subject knowledge to code a set of questions in their area of expertise for a single country or, occasionally, several countries. A Bayesian item response theory (IRT) model converts these answers into a continuous scale that returns the values of the latent level of a given phenomenon observed by the coders. Theoretically, values for each indicator vary from minus infinity to plus infinity. In reality, values are usually bounded around -3 and 3 . Table A2 in the supplementary material shows the range of values for every indicator. ${ }^{59}$

\footnotetext{
${ }^{55}$ In addition, "new growth theory" and evolutionary theories of growth submit that human capital accumulation has persistent, longer-term growth effects; see, e.g., Acemoglu 2009; Nelson 2005.

${ }^{56}$ E.g., Acemoglu 2009.

${ }^{57}$ Simmons 2016. See also Doner 2009.

${ }^{58}$ Bizzarro et al. 2018b.

${ }^{59}$ Bizzarro et al. 2018b.
} 
In the expert questionnaire, V-Dem coders were asked to evaluate countries, not individual parties. To ensure that coders would consider only the set of "minimally relevant" parties in a country, they were asked to consider parties running for "national-level offices" (national organizations), or the main parties in a system (party linkages). The coding unit is thus at the country-year level, not the party level. ${ }^{60}$

The six indicators are standardized and averaged together to form a party strength index reflecting the expectation that each element of the index is partially substitutable. It bears emphasizing that the empirical results shown in subsequent tables are robust to the omission of any of these indicators. Thus, scholars who favor a somewhat narrower conceptualization of party strength can take comfort: our results do not hinge on the inclusion of any particular indicator. Results are also robust to alternate aggregation rules for the index, for example principal components analysis or multiplication (see Table B2 in the supplementary material). ${ }^{61}$

Figure 2 presents a histogram of the party strength index for all 16,413 country-year observations in the data set, revealing a distribution that approximates a normal curve. The index varies from -1.69 to 1.42 , with median and mean values of 0.04 and 0.00 , respectively, and a standard deviation of 0.54 (see Table A2 in the supplementary material). When observed over time across our global sample, this shows a slight, long-term secular increase with sharp periodic variations, that is, a strong increase right after World War II and a small decline around 1990 (coinciding with the collapse of Communist one-party regimes in Eastern Europe and the introduction of multiparty politics in many African countries), shown in Figure $\mathrm{C} 1$ in the supplementary material.

Cross-country variation at any given point in time is substantial. Some countries are characterized by strong parties (Sweden, Germany, Spain, the Netherlands, Belgium, Uzbekistan, Denmark, China, and Vietnam in 2011) and others by weak or no parties (Papua New Guinea, Haiti, Saudi Arabia, Qatar, and Liberia in 2011). ${ }^{62}$ Point estimates for

\footnotetext{
${ }^{60}$ Further information about these indicators and discussion of how they map onto the definitional attributes of the key concept (party strength) is contained in Appendix B in the supplementary material (Bizzarro et al. 2018b). Appendix E contains further discussion about the validity of the measure, contrasting it to a widely used proxy of party institutionalization. Information about the recruitment of expert coders, coding procedures, and cross-coder aggregation is contained in Appendix D. Details about the IRT measurement model used to arrive at point estimates and confidence intervals for each indicator are contained in Coppedge et al. 2017b and Pemstein et al. 2017. Additional discussion about the indicators and their characteristics is available in Bizzarro, Hicken, and Self 2017, which explores many of the political party variables contained in the $\mathrm{V}$-Dem data set.

${ }^{61}$ Bizzarro et al. 2018b.

${ }^{62}$ Countries with intermediate levels of party strength generally combine higher scores in the scope variables, indicating that all parties attain a minimum level of organization (with national organizations and local branches) with lower scores in the depth dimension of the index (legislative cohesion,
} 


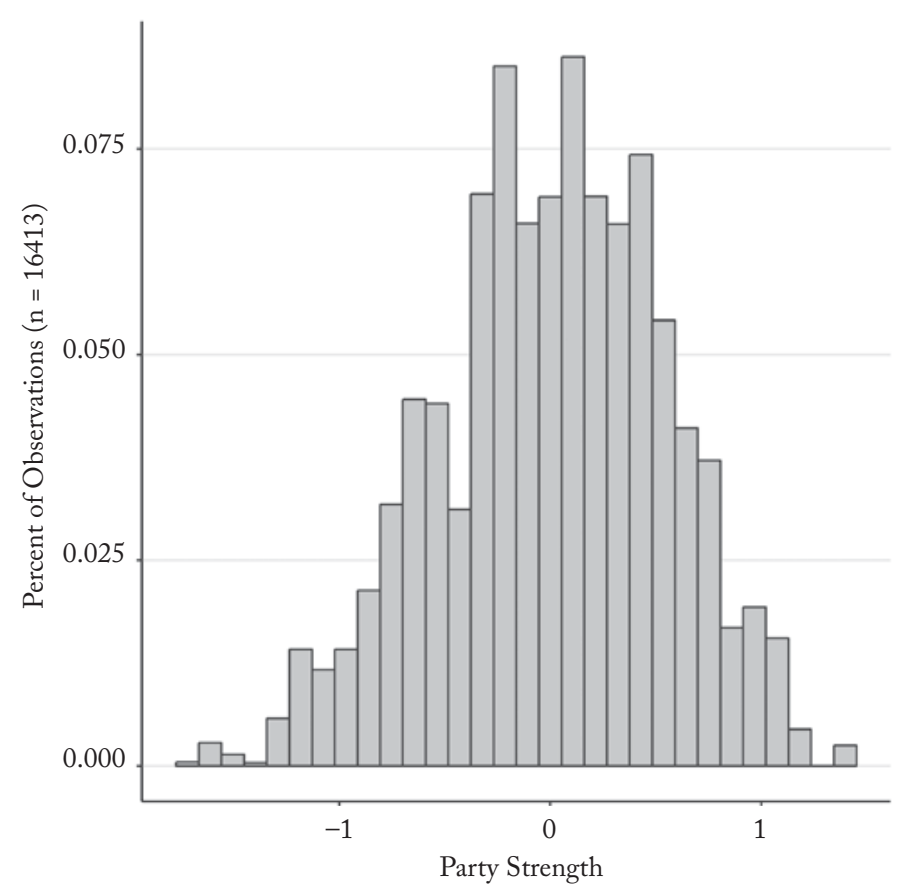

FIGURE 2

Distribution of Party Strength Values

all countries in 2011 are listed in Table $\mathrm{C} 1$ in the supplementary material. Importantly, not all point estimates are clearly distinguishable, as signaled by the confidence intervals accompanying each score.

Convergent validity tests, shown in Appendix D in the supplementary material, indicate that our index is associated with other indicators often regarded as measures of party strength or institutionalization. For example, party strength is positively correlated with party age (average age of the three largest parties in the legislature) and party system institutionalization (a stable and socially rooted party system), and negatively correlated with electoral volatility (change in share of votes

programmatic linkages). One example of this combination is Brazil (with a score of 0.04 in 2011), where all the main parties have become nationally organized, but where programmatic competition is comparatively less salient. Conversely, other intermediate cases are competitive authoritarian regimes where the rulling party is strong (and thus, the country scores high in variables like legislative cohesion) but the opposition is weak, leading coders to report inequality in levels of organizational strength among the parties in the country (Zimbabwe, with a score of -0.01 in 2001, is an example). 
received from election to election), shown in Table D3 in the supplementary material..$^{63}$ Among relatively autocratic countries, party strength is much higher in regimes categorized as single party, one party, or dominant multiparty, than in regimes categorized by Barbara Geddes and colleagues or Axel Hadenius and Jan Teorell as personalist, military, or monarchic (see tables D1 and D2 in the supplementary material).$^{64}$

It is worth noting that the party strength index is modestly associated with commonly used measures of good governance (for example, the worldwide governance indicators), state history, ${ }^{65}$ state capacity, ${ }^{66}$ and democracy (for example, Polity2), shown in Table D3 in the supplementary material. Specifically, party strength is somewhat higher in democracies and in countries that exhibit higher degrees of rule of law and control of corruption. But the modest correlations suggest that party strength is not reducible to these ancillary concepts, and our index is therefore unlikely to serve a proxy role in the tests that follow. To ensure that this is not the case, we include variables measuring democracy, state capacity, property rights, and so forth, as covariates in several robustness tests.

\section{REgional ANALYSis}

To provide further validation of the index and to preliminarily check some of our theoretical expectations, we begin our empirical foray by exploring East/Southeast Asia. By common understanding, this region includes Burma/Myanmar, Cambodia, China, Indonesia, Japan, Laos, Malaysia, North and South Korea, the Philippines, Taiwan, Thailand, and Vietnam. We exclude microstates (Hong Kong, Singapore, Timor Leste, and Brunei) and countries generally classified as part of the Oceanic region (including Australia and Papua New Guinea).

Although some regions, such as Western Europe, feature parties that are generally quite strong, and others, such as Africa, feature parties that are generally quite weak, East/Southeast Asia encompasses considerable diversity. This empirical diversity provides useful analytical leverage for assessing the effects of party strength. Of course, being

\footnotetext{
${ }^{63}$ Especially since party age (from the DPI data set) has been used by extant studies on the institutional determinants of growth to capture party institutionalization in autocratic settings, we provide a detailed discussion on how our party strength index relates to this widely used measure in Appendix E; Bizzarro et al. 2018b.

${ }^{64}$ Geddes, Wright, and Frantz 2014; Hadenius and Teorell 2007.

${ }^{65}$ Bockstette, Chanda, and Putterman 2002.

${ }^{66}$ Hanson and Sigman 2013.
} 
situated in the same geographic region does not mean that equal conditions have been achieved. Nonetheless, it provides ex ante plausibility for making cross-country comparisons given that countries in the same region are likely to share many cultural, geographic, and historical features.

An extensive literature suggests that some high-performing Asian economies were governed by dominant parties that enjoyed long time horizons, had the power to maneuver around potential veto points, could shield the bureaucracy from special interests, and could effectively oversee policy implementation. ${ }^{67}$ Although these tasks might be carried out without a strong party (as the Thai case to some extent demonstrates), parties seem to have served as an alternate route to economic development-one that may be especially important in countries without a strong state tradition.

This impression is bolstered when comparing party strength (as measured by our index) to growth rates over the postwar period, as shown in Figure $3{ }^{68}$ Countries with strong growth trajectories (China, Vietnam, Taiwan, Japan, and Malaysia, for example) are generally characterized by stronger parties. The index is centered on zero, so positive scores signal above-average scores across the entire sample, which includes most sovereign and semi-sovereign countries globally from 1900 through 2012.

Of course, the group of countries classified as members of East/ Southeast Asia are heterogeneous along a number of dimensions that may be expected to affect party strength and economic development. Arguably, a more satisfactory most-similar analysis may be attained by focusing on a smaller group of countries that are more homogeneous on background characteristics. For this focused comparison, we choose Indonesia, Malaysia, the Philippines, and Thailand. These four countries have long coastlines and are therefore similarly exposed to international currents carrying trade, technology, and ideas. They have no history of communist control or of the total colonial control exercised by Japan and often regarded as a modernizing force. ${ }^{69} \mathrm{Ex}^{-}$ cept for Thailand, which was never colonized, they attained independence at about the same time. And they had comparable socioeconomic

\footnotetext{
${ }^{67}$ Again, there are important differences among states along each of these dimensions. See, e.g., MacIntyre 1994.

${ }^{68}$ The slope of the best fit line in the graph is 0.90 , fairly similar to the coefficient (1.41) in our baseline test (Table 1, model 1).

${ }^{69}$ Kohli 1994.
} 


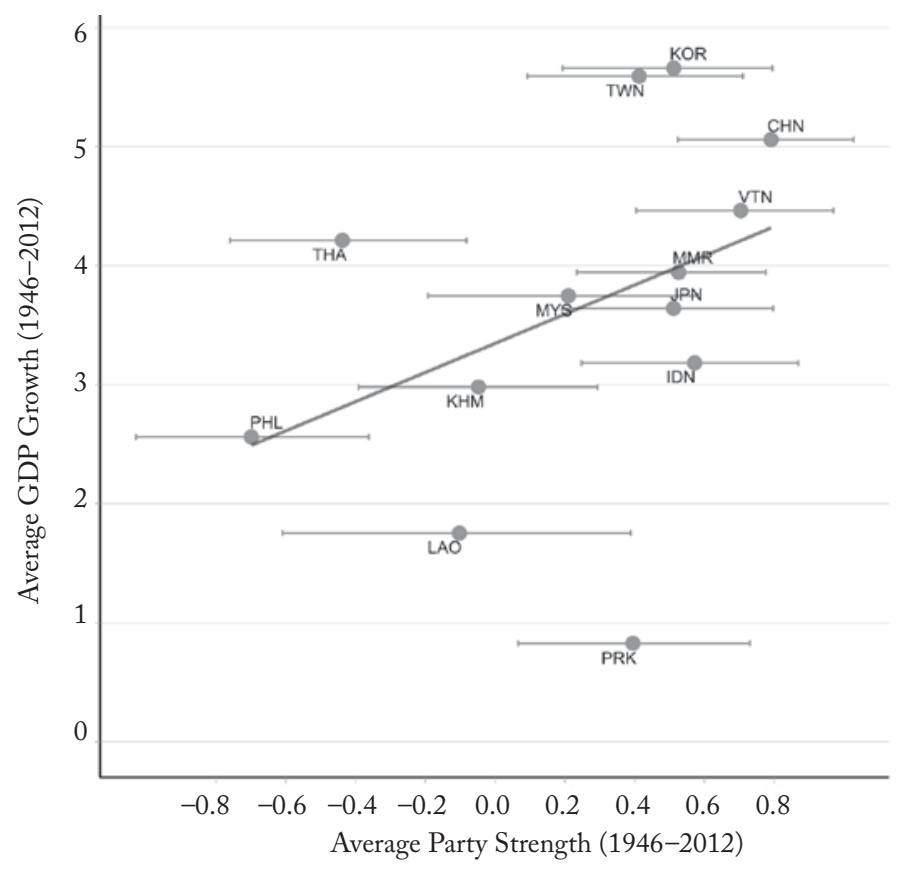

\title{
FIGURE 3 \\ East Asian and Southeast Asian Cases at a Glance ${ }^{a}$
}

\begin{abstract}
${ }^{\text {a }}$ Party strength and per capita GDP growth averaged across the 1946-2012 period. Seventy percent highposterior density intervals based on posterior distribution of point estimates (see Coppedge et al. 2015b). Best fit line (slope: 0.902) resulting from a bivariate regression of the mean of per capita GDP growth (1946-2012) on the mean of party strength (1946-2012) for the following countries: MMR (Burma/ Myanmar), KHM (Cambodia), CHN (China), IDN (Indonesia), JPN (Japan), LAO (Laos), MYS (Malaysia), PRK (North Korea), PHL (Philippines), KOR (South Korea), TwN (Taiwan), THA (Thailand), and VTN (Vietnam).
\end{abstract}

characteristics at mid-century as measured by per capita GDP, education, and urbanization. ${ }^{70}$

Figure 4 plots party strength for these cases over the past century and includes periods of colonial rule, as coded by V-Dem. Several features of this comparison are notable. First, corresponding with scholarly consensus, Thailand and the Philippines consistently register the lowest levels of party strength. In both countries, parties are generally described as ephemeral alliances of convenience with little commitment

\footnotetext{
${ }^{70}$ For example, GDP per capita in 1950 was $\$ 1,070$ for the Philippines, $\$ 817$ for Indonesia and Thailand, and \$1,559 for Malaysia. Retrieved from The Maddison-Project (2013 version) at http://www.ggdc .net/maddison/maddison-project/home.htm.
} 


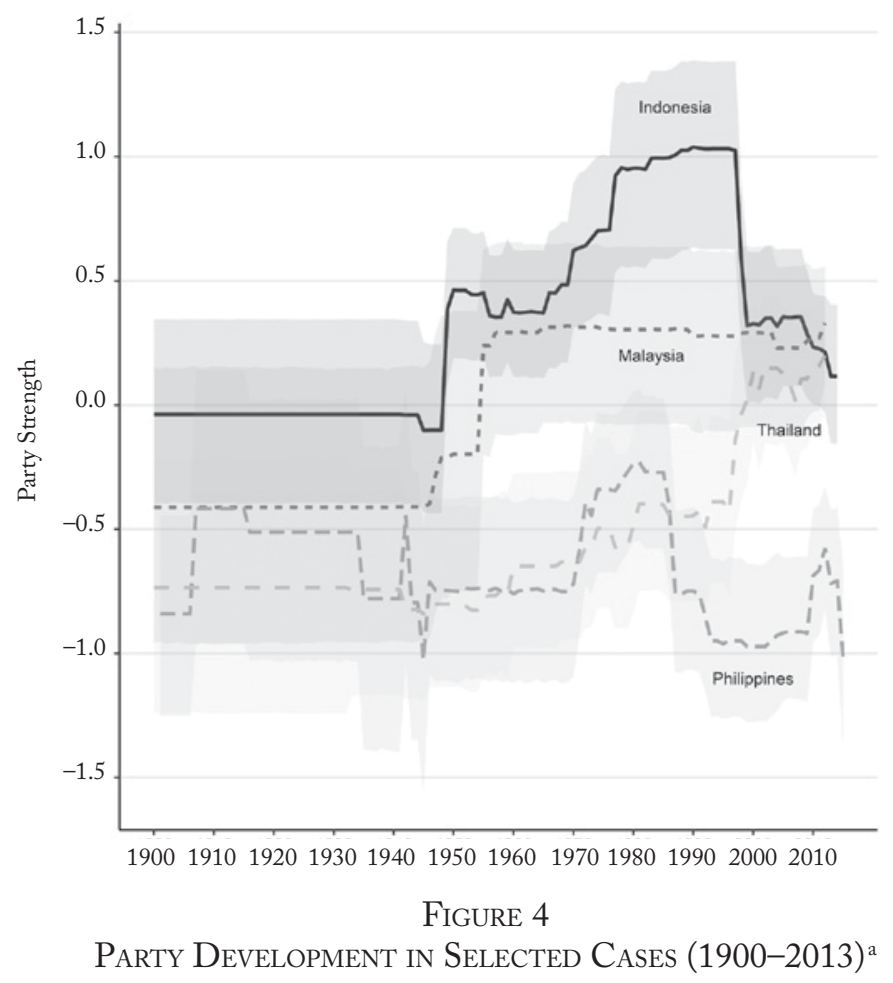

${ }^{\text {a }}$ Party strength through time for selected East Asian and Southeast Asian cases, including preindependence periods. Seventy percent high-posterior density intervals based on posterior distribution of point estimates (see Coppedge et al. 2017b).

to program or ideology and only tenuous connections to voters and societal groups. ${ }^{71}$ They stand in sharp contrast to Indonesia and Malaysia, where party strength has historically been much stronger. ${ }^{72}$

The party strength index also appears to capture important changes to party systems over time, as described in the scholarly literature. For example, the time-series for Thailand shows a modest increase in party strength beginning in the late 1990s, which corresponds to changes in the Thai party system following the 1997 constitutional reforms and the rise of Thaksin Shinawatra and the Thai Rak Thai party. ${ }^{73}$ Malaysia exhibits an increase in party strength in the 1950s, reflecting the creation of three ethnically based parties (UMNO, MCA, and MIC) and their banding together in the ruling alliance - a pact that has formed the

${ }^{71}$ Brownlee 2007; Croissant and Volkel 2012; Hicken and Kuhonta 2015; Hutchroft and Rocamora 2003; Quimpo 2005; Ufen 2012.

${ }^{72}$ Kuhonta 2011.

${ }^{73}$ Hicken 2013. 
core of the ruling coalition ever since. Indonesia's score picks up during the period of turbulent party competition after the country's independence in 1945, which pitted secular nationalist, communist, and Islamic parties against each other. It also captures the substantial increase in party strength accompanying the creation of Hajji Suharto's ruling Golkar party (Partai Golongan Kary) in the late 1960s. And it registers the decline in strength and rootedness of parties corresponding to the return of democracy in 1998 . The index additionally shows a modest decline in party strength in Indonesia beginning in 2005, dovetailing with accounts highlighting the deinstitutionalization of Indonesia's party system, which accelerated after the switch to open-list proportional representation (PR) in 2008. ${ }^{74}$

Considering more closely the cases of Malaysian and the Philippines, Figure 4 shows a large gap in party strength throughout the contemporary period, a feature that may help to explain their divergent economic trajectories in the late twentieth century. With its institutionalized and pragmatic parties, Malaysia was poised to "create organizational power that is necessary to drive through social reforms, provide capacity and continuity that sustain and protect a reform agenda, and maintain the ideological moderation that is crucial for balancing propoor measures with growth and stability." ${ }^{75}$ Its economic performance over the past half-century is impressive. By contrast, the Philippines has featured weak parties distinguished by their lack of interest in programmatic policies and a striking lack of institutionalization. Philippine parties "are characterized by factionalism, frequent party switching ... and party labels that generally mean little to voters or candidates. As a result they ... are not cohesive unitary actors pursuing unique policy agendas. Rather, they are temporary alliances of narrowly oriented politicians primarily concerned with distributing the spoils of government ... to themselves and their supporters." 76 This in turn has contributed to a chronic undersupply of collective goods and comprehensive national policies, which by all accounts has stunted growth prospects. ${ }^{77}$ At the conclusion of World War II, the Philippines was one of the wealthiest countries in the region, behind only Japan and Malaysia. But beginning in the 1970s and extending until very recently, other countries surged ahead, leaving the Philippines as the perennial sick man of East/ Southeast Asia.

\footnotetext{
${ }^{74}$ Aspinal 2014.

${ }^{75}$ Kuhonta 2011, 4.

${ }^{76}$ Hicken 2008, 223.

${ }^{77}$ Hutchcroft and Rocamora 2003; Mackie and Villegas 1999.
} 
Scholars of the Philippines describe four mechanisms by which weak parties undermined growth, closely corresponding to the argument outlined in Section I. First, weak parties have been unable to transcend the powerful economic interests that have long dominated Philippine politics. ${ }^{78}$ As a result, public policy caters to the narrow interests of groups in the elite at the expense of broader interests espoused by social groups and organizations. ${ }^{79}$ Second, weak parties, often the vehicles of powerful personalities, are unable to constrain party leaders, particularly presidents. Hence, Philippine policy has been dependent on the peculiar preferences and personalities of individuals, which undermines the predictability and credibility of policy. ${ }^{80}$ Third, weak parties have meant that Philippine politicians operate with very short time horizons ${ }^{81}$ yielding chronic underinvestment or inefficient investment in public services, human capital, and physical infrastructure. Fourth, the failure of parties to adequately respond to broader societal interests has meant that pressures for reform often take "extra-parliamentary-and even extra-legal-forms ...", ${ }^{82}$ resulting in periodic eruptions of political instability and a concomitant erosion of investor confidence.

In the section below, we show that the apparent relationship between party strength and economic growth is not restricted to the East/ Southeast Asian context, but rather reflects a general pattern found throughout the world in the modern era.

\section{Main Tests}

The following empirical tests include most sovereign countries observed annually across the past century. Analyses of GDP per capita growth ${ }^{83}$ employ a variety of estimation techniques, specifications, samples, time-lag specifications, and measures of key concepts. Specification tests include covariates measuring other institutional features of proposed relevance for growth, such as regime type, property rights protection, and state capacity. The main result, showing that party strength enhances economic growth, is robust to an extent that has few parallels in the literature on institutions and growth.

We begin with a parsimonious specification, displayed in model 1, Table 1. In it, growth is regressed on party strength in an oLs model

\footnotetext{
${ }^{78}$ Hutchcroft 1998.

${ }^{79}$ de Dios and Hutchcroft 2003.

${ }^{80}$ Balisacan and Hill 2003; Hutchcroft 2000.

${ }^{81}$ Pascual and Lim 2001.

${ }^{82}$ Hutchinson 2001, 57.

${ }^{83}$ Obtained from Bolt and van Zanden 2014.
} 


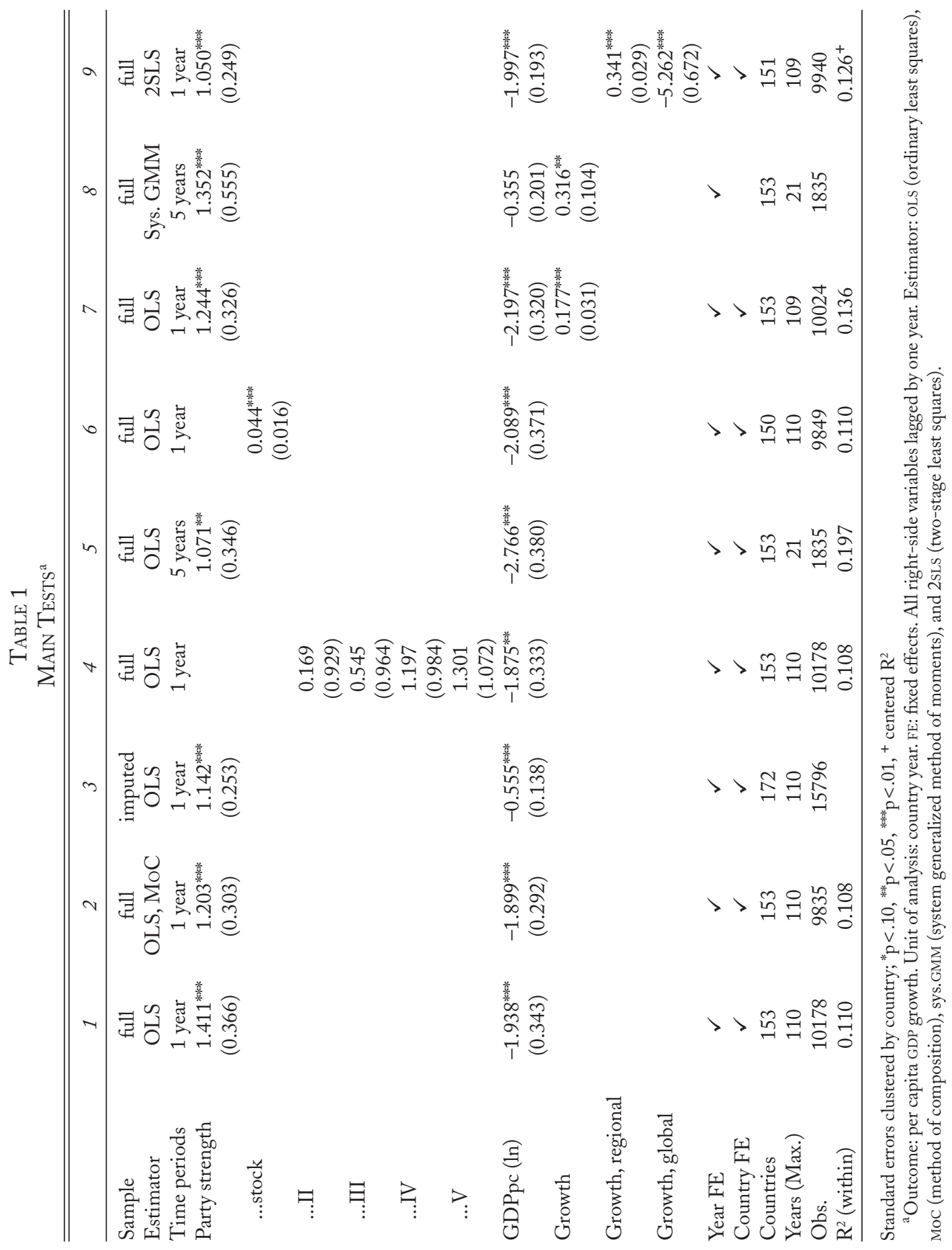


along with year and country fixed effects, and GDP per capita (logged). The latter is intended to account for convergence effects ${ }^{84}$ and the possibility that parties may be stronger in richer countries. The benchmark model employs robust errors clustered by country to correct for panelspecific autocorrelation and incorporates 10,178 observations from 153 countries observed annually from 1901 to 2010 . All right-side variables are lagged one period (year) behind the outcome. This specification should capture short-term effects of party strength on growth. In accordance with our theoretical discussion, we also probe alternate specifications that are appropriate for capturing long-term effects.

The estimated coefficient and standard error for party strength in model 1 indicate a strong relationship with subsequent growth. Based on that model, Figure 5 plots the estimated impact of hypothetical changes in party strength, surrounded by 95 percent confidence intervals. Holding initial level of income constant and controlling for country and year fixed effects, the beta estimate suggests that a one-point increase in the party strength index boosts GDP per capita growth the subsequent year by about 1.4 percentage points. A one-point difference in party strength is similar to the difference in 2010 scores separating the cases of Malaysia (0.26) and the Philippines (-0.76), discussed above. Such a difference in party strength has substantial consequences for economic development over time. Model 1 in Table 1 suggests that if two otherwise equal countries start out today with the 2010 party strength scores of Malaysia and the Philippines, respectively, the former will grow to be twice as rich (104\%) in about fifty years.

Subsequent tests address measurement error, sample bias, functional form, intermediate and longer-term effects, endogeneity, and reverse causality. Omitted variable bias and the context-sensitivity of the effect are discussed in Section V.

To assess the potential role played by measurement error, model 2 replicates model 1 with the incorporation of uncertainty estimates produced by the V-Dem measurement model for the party strength index. Although those who study country-level phenomena may recognize measurement error informally, it is rarely incorporated into estimators. $\mathrm{V}$-Dem is virtually unique among institutional measures insofar as it draws on multiple coders whose ratings are combined with a Bayesian IRT measurement model to produce an estimate as well as a confidence interval (see Appendix D in the supplementary material). ${ }^{85}$ Using the

\footnotetext{
${ }^{84}$ Barro and Sala-i-Martin 1990.

${ }^{85}$ Bizzarro et al. 2018b; see also Pemstein et al. 2017.
} 


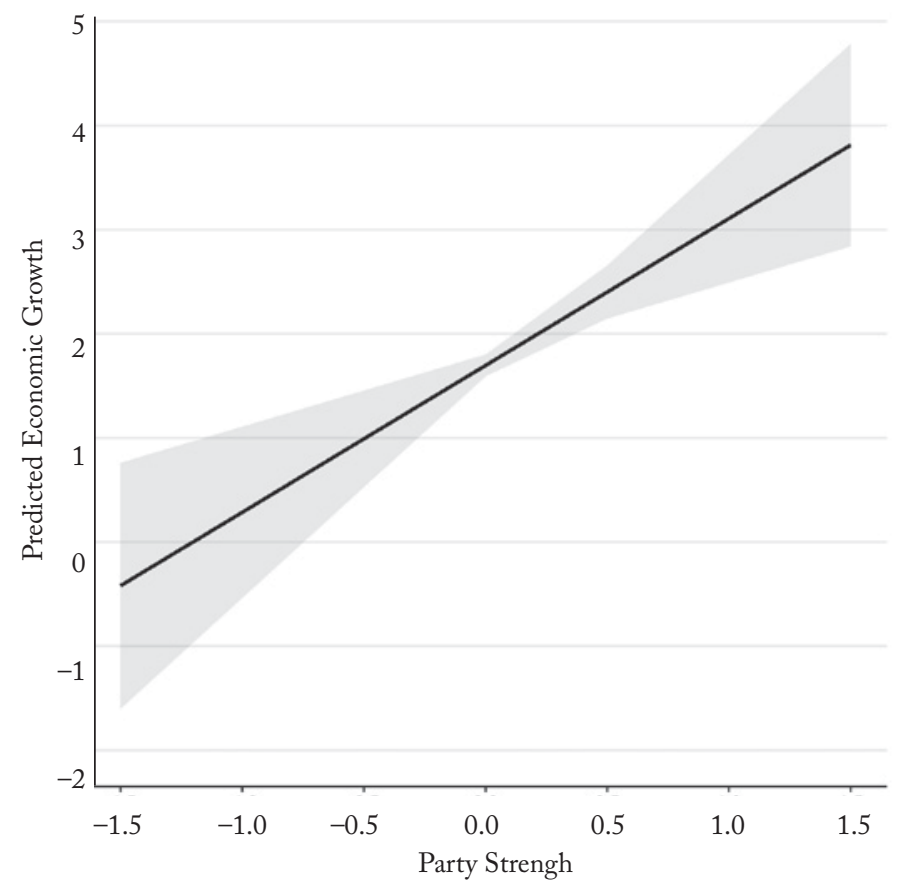

FiguRE 5

\section{Party Strength and Predicted GDP Per Capita Growtha}

\footnotetext{
${ }^{\text {a }}$ Predicted growth rates, surrounded by 95 percent confidence intervals, as a function of party strength based on model 1, Table 1, with GDP per capita set at its mean, country, and year fixed effects, and standard errors clustered by country.
}

method of composition, ${ }^{86}$ we run our benchmark model on nine hundred draws of the posterior distribution estimated for the party strength index (resulting from the aggregation of the posteriors of each indicator). The resulting coefficients and standard errors are very similar to those reported in model 1, demonstrating that the association is robust even when accounting for measurement uncertainty in party strength ${ }^{87}$

Another threat to inference is posed by sample bias, a product of the fact that data for key variables are not available for all countries. To

${ }^{86}$ Bizzarro, Pemstein, and Coppedge 2016; Pemstein et al. 2010.

${ }^{87}$ Other tests point in the same direction. There may be more reason to expect unsystematic and possibly systematic measurement errors in the more subjective indicators included in our index, such as the programmatic parties versus clientelistic linkages measure. But robustness tests show that results are not sensitive to including only subsets of the indicators, even the more objective ones, such as party switching and the existence of national party organizations and regional branches. Results also are not sensitive to using different aggregation techniques for our main index (see Table F1 in the supplementary material, which displays models relying on alternative index formation strategies and reduced indices excluding each individual indicator; Bizzarro 2018b). 
mitigate this problem we employ the Amelia II multiple imputation algorithm ${ }^{88}$ adapted to the cross-section time-series structure of our data (for more information see Appendix F in the supplementary material). Ten imputed data sets are produced, encompassing 173 countries and a time series extending from 1900 to 2015. Model 3 reports the coefficients for the benchmark model, averaged across these imputed data sets and with standard errors that reflect variability across data sets. The effect of party strength on growth remains positive and significant $(\mathrm{p}<.001)$, with a magnitude similar to the benchmark model.

We also want to ensure that the result is not subject to strong assumptions about functional form. To investigate this, we construct an ordinal measure representing different levels of party strength. Dummies are constructed by dividing up the index, which stretches from -1.69 to 1.42 , into five equidistant units. These dummies (I-V) replace our continuous measure of party strength in model 4: the first level constitutes the reference category. For our purposes, the salient result is that the coefficients increase monotonically from I to V, suggesting that our index captures the true functional form quite well. It also reassures us that the effect reported in the benchmark model is not driven by a few unusual cases.

Next, we turn to tests that investigate medium- and long-term effects on growth, as anticipated by our argument. To assess intermediate effects, model 5 in Table 1 employs variables measured across five-year intervals, rather than annually. Specifically, we generate a moving average of all variables and then run the benchmark model on every fifth year $(1900,1905,1910, \ldots)$. This reduces the amount of information available and blunts proximal relationships that may exist between party strength and growth. But it also reduces noise from short-term business cycles and models the relationship in a more distal manner: a fiveyear lag replaces the one-year lag. Although the point estimate for party strength is reduced, the relationship persists and remains statistically significant $(\mathrm{p}<.01)$.

Another approach to investigating long-term effects is to consider a country's overall historical experience with party strength. Model 6 follows Gerring and colleagues ${ }^{89}$ by generating a stock variable that summarizes party strength scores over a country's entire observed time series. The annual discount rate is set very low, at 1 percent, to ensure that party strength scores going back several decades carry significant

\footnotetext{
${ }^{88}$ Honaker, King, and Blackwell 2011.

${ }^{89}$ Gerring et al. 2005.
} 
weight in the present. The estimated coefficient is positive and highly significant, suggesting that party strength has long-term-in addition to short- and intermediate-term-effects on growth. ${ }^{90}$

This conclusion also holds up when estimating the long-term effect of party strength on growth using other specifications. In Table G3 in the supplementary material, we show variations of the benchmark where we separate right- and left-side variables by a longer interval (Table F3, models 3-6), and lag annualized party strength scores by more than one year. The estimated impact decreases in magnitude as we move farther from the outcome, but remains significant even when we measure party strength ten years before the outcome $(p<0.1)$.

We also employ "long distance" estimators, similar to those used by Daron Acemoglu and Simon Johnson. ${ }^{91}$ These models, reported in Table G4 in the supplementary material, analyze only two observations separated by a long period of time and estimate the effect of changes in the predictor on changes in the outcome. Because we need to balance the length of the time series against the concern of including as many countries as possible, we extend the analysis from 1956 to 2006. We find a positive coefficient $(\mathrm{p}<0.1)$ in the full sample of 125 countries that have data for all variables in 1956 and 2006. Overall, these analyses corroborate that party strength has both short- and long-term effects on GDP per capita growth.

Specifications introducing longer time lags between the independent and dependent variables should also help to reduce simultaneity bias, but they are no safeguard against reverse causality. Low growth rates could, for example, result in fewer resources being available to parties, leading to the dismantling of expensive regional party organizations. Poor economic performance may also give incumbent party members incentives to vote against their party or even to switch party allegiances to cater to dissatisfied voters. We turn now to a series of tests that try to mitigate the possibility of $\mathrm{X}-\mathrm{Y}$ endogeneity.

Model 7 in Table 1 replicates the benchmark specification with the addition of a lagged dependent variable (growth) on the right side. In this way, we can account for the possibility that past growth may drive party features and current growth. This dynamic model estimates how party strength at $t-1$ affects changes in the economic growth rate from $t-1$ to $t$. Point estimates and t-values are very close to our benchmark

\footnotetext{
${ }^{90}$ This result also offers some assurance that the relationship between party strength and growth is not the product of simultaneity - an issue we return to below-as the stock variable extends back to 1900 (the first year in which party strength is observed for a country).

${ }^{91}$ Acemoglu and Johnson 2007.
} 
model. The estimated short-term effect of a one-unit increase in party strength is a 1.2 percentage point increase in the growth rate. The estimated long-term effect, which is conventionally calculated as $\beta_{\mathrm{IV}}$ / $\left(1-\beta_{\text {lagged DV }}\right)$ in autoregressive models, is a 1.5 percentage point higher annual growth rate.

We test several other specifications that include alternate sets of lags of growth as regressors, and the benchmark result remains robust. We also switch the positions of the outcome (economic growth) and our main predictor (party strength) to check whether lagged economic growth predicts changes in party strength (Table G3, model 2). We find no association between the previous year's rate of economic growth and subsequent increases in party strength.

In model 8, we test a more complex dynamic panel model known as system generalized method of moments (GMM), which explicitly models regressors as endogenous. ${ }^{92}$ This version of GMM is regarded as appropriate for studying sluggish variables, such as party strength, ${ }^{93}$ and is more efficient than the original difference GMM estimator. ${ }^{94}$ System GMM is widely used in the growth literature, including studies of democracy and growth. ${ }^{95}$

Initial tests using the benchmark specification reveal extremely large and highly significant coefficients for party strength. But model diagnostics suggest that the over-identifying restrictions may not be valid

\footnotetext{
${ }^{92}$ Blundell and Bond 1998. The system GMM estimator includes level and differences regressions, and accounts for endogenous regressors by using lags of levels to instrument for differences and lags of differences to instrument for levels. Two lags (second and third) are used for instrumentation to mitigate the "too-many-instruments" problem (see Roodman 2009), and party strength and lagged growth are modelled as endogenous. The $\mathrm{AR}(2)$ test $\mathrm{p}$-value is 0.06 , and the Hansen J-test p-value is 0.60. We tested various other GMM models, for instance, only considering party strength as endogenous or altering the number of lagged dependent variables or lags used for instrumentation, and the coefficient on party strength is quite stable and robust.

${ }^{93}$ One indication of the sluggishness of party strength, and thus the appropriateness of the system GMM strategy, comes from studying versions of our benchmark adopting various leads, rather than lags, of party system as the independent variable. Even though we do not find that past levels of party strength predict growth, regressions employing the lead of party strength rather than the lag show positive and often significant results. Nevertheless, the lags of party strength outperform the leads in terms of coefficient sizes. To further test how this feature of the data may influence results, we replaced OLS with a generalized estimating equation (GEE) estimator (Table G5, Appendix F; Bizzarro et al. 2018b). Although (linear) GEE models are similar to fixed-effects models (they aim at measuring population averaged effects), they allow for explicitly modeling the temporal correlation between observations. Reassuringly, the GEE models in Table G5 show remarkably similar results to our benchmark, regardless of the correlation structure we adopt.

${ }^{94}$ Arrelano and Bond 1991.

${ }^{95}$ One difference between our specification and that used by many growth economists, such as Levine, Loayza, and Beck 2000, is that we employ GDP per capita growth as the dependent variable rather than logged GDP per capita levels. See Knutsen 2013 for a discussion on this specification choice and its implications in the context of how democracy and state capacity affect growth. We robustnesstested several GMM specifications using logged GDP per capita as dependent variable and the party strength coefficient is robust.
} 
with annualized data due to the large number of instruments. Thus, we follow a standard approach for GMM models that incorporate long time series by recoding annual data at five-year intervals (as in model 4). ${ }^{96}$ Doing so reduces the number of time series units and hence the number of instruments, allowing for valid identification following the assumptions of the model. We allow two lags for instrumentation, producing 139 instruments. This is well below the number of cross-sectional units (153) often regarded as a rule-of-thumb threshold. ${ }^{97}$ The Hansen J-test $p$-value suggests that model 8 provides consistent estimates. Even when modelling party strength as endogenous, the GMM model estimates that the short-term effect of a one-point increase in party strength results in 1.3 percentage points additional growth (significant at 0.1 percent $)$, and the long-term effect $\left(\beta_{\text {party strength }} /\left(1-\beta_{\text {lagged }}\right.\right.$ DV) is about 2 percentage points.

In model 9, we apply an instrumental-variable approach to further ensure that our results are not critically affected by model endogeneity. To instrument for party strength we adopt an instrumentation technique developed for testing the effects of institutional features on economic performance. ${ }^{98}$ This instrument rests on the assumption that institutional forms are, in part, the product of diffusion. ${ }^{99}$ Insofar as we can measure pressures for diffusion by taking account of the institutional forms adopted by a country's neighbors, and insofar as the institutional evolution of these neighbors has no direct impact on the outcome of interest (conditional on the other covariates), this diffusion instrument satisfies the exclusion restriction.

Specifically, we construct a variable that measures average levels of party strength in a region (excluding the country in question) and another variable that measures average values of party strength globally (also excluding the country in question), with the expectation that these regional and global factors predict party strength in the country of interest. F-tests of these instruments in the first-stage regression corroborate that they are very strong predictors, explaining a substantial amount of variation in party strength (see Table H1 in the supplementary material). We also include as regressors two variables measuring average growth rates regionally and globally to mitigate the possibility that our diffusion instruments are correlated with economic performance (violating the exclusion restriction). The Hansen J-test suggests

\footnotetext{
${ }^{96}$ E.g., Levine, Loayza, and Beck 2000.

${ }^{97}$ Roodman 2009.

${ }^{98}$ Acemoglu et al. 2014; Knutsen 2011a; Miller 2015; Persson and Tabellini 2003.

${ }^{99}$ Weyland 2008.
} 
that the validity of exclusion restriction cannot be rejected at the 5 percent level, and the estimated coefficient for party strength in model 9, which is similar to our benchmark model, might thus yield a consistent estimate of the effect of party strength on growth. ${ }^{100}$

A final test designed to assuage concerns of endogeneity bias reruns the benchmark, but alters our main independent variable (model 2, Table G1, in the supplementary material). More specifically, we remove the three indicators that we theoretically expect are more likely to be affected by growth (and that figure in the causal chain in our theoretical argument). These are party linkages, party cohesion, and party switching. An economic recession could, for example, lead to political turmoil, with many legislators voting against their own parties to cater to protest voters or even switching parties. When rerunning our benchmark on a reduced index including only the three indicators capturing how parties are structured (permanent employees, permanent branches, candidate selection), the association between party strength and growth is positive (1.03), and clearly distinguishable from zero $(t=2.9) .{ }^{101}$

\section{Additional Confounders and Context Sensitivity}

In Table 2, we conduct a series of tests intended to probe the sensitivity of the party strength/growth relationship to potential confounders. ${ }^{102}$ All variables are defined in Table A 1 in the supplementary material, and descriptive statistics are shown in Table A2.

Model 1 of Table 2 is a spare model including only country and year dummies. Model 2 deals with temporal confounders by measuring oneperiod changes in the main independent variable and economic growth as the dependent variable - a first-difference model. Model 3 adds several time-varying covariates to the benchmark specification, including

\footnotetext{
${ }^{100}$ To test the stability of this result, we conduct a number of robustness tests, employing different sets of instruments and controls, as shown in Table H2 in the supplementary material (Bizzarro et al. 2018b). Results suggest that our specification is not susceptible to arbitrary choices of instruments.

${ }^{101}$ The other models in Table G1 in the supplementary material provide additional evidence of the robustness of our findings. Models 3 to 8 replace the index by each of its components. All coefficients are positive, indicating that the main association between stronger parties and economic growth is consistent regardless of the characteristic of the parties that we measure. A few of the coefficients are statistically different from 0 (party branches, legislative cohesion, and national candidate selection, at $\mathrm{p}<.10)$. This combination of results is reassuring because although it was reasonable to expect that correlations should be positive on average given the robustness of the main result, the theory predicts that it is the combination of factors that actually drives the results.

${ }^{102}$ The sample varies in Table 2 due to differences in missing values on the different controls, and subsequent list-wise deletion. Table G9 in the supplementary material compares each model in Table 2 with the benchmark for identical samples, and Table G10 displays similar specifications as in Table 2 for a constant sample across all the models in the table.
} 
TABle 2

Specification Tests ${ }^{\mathrm{a}}$

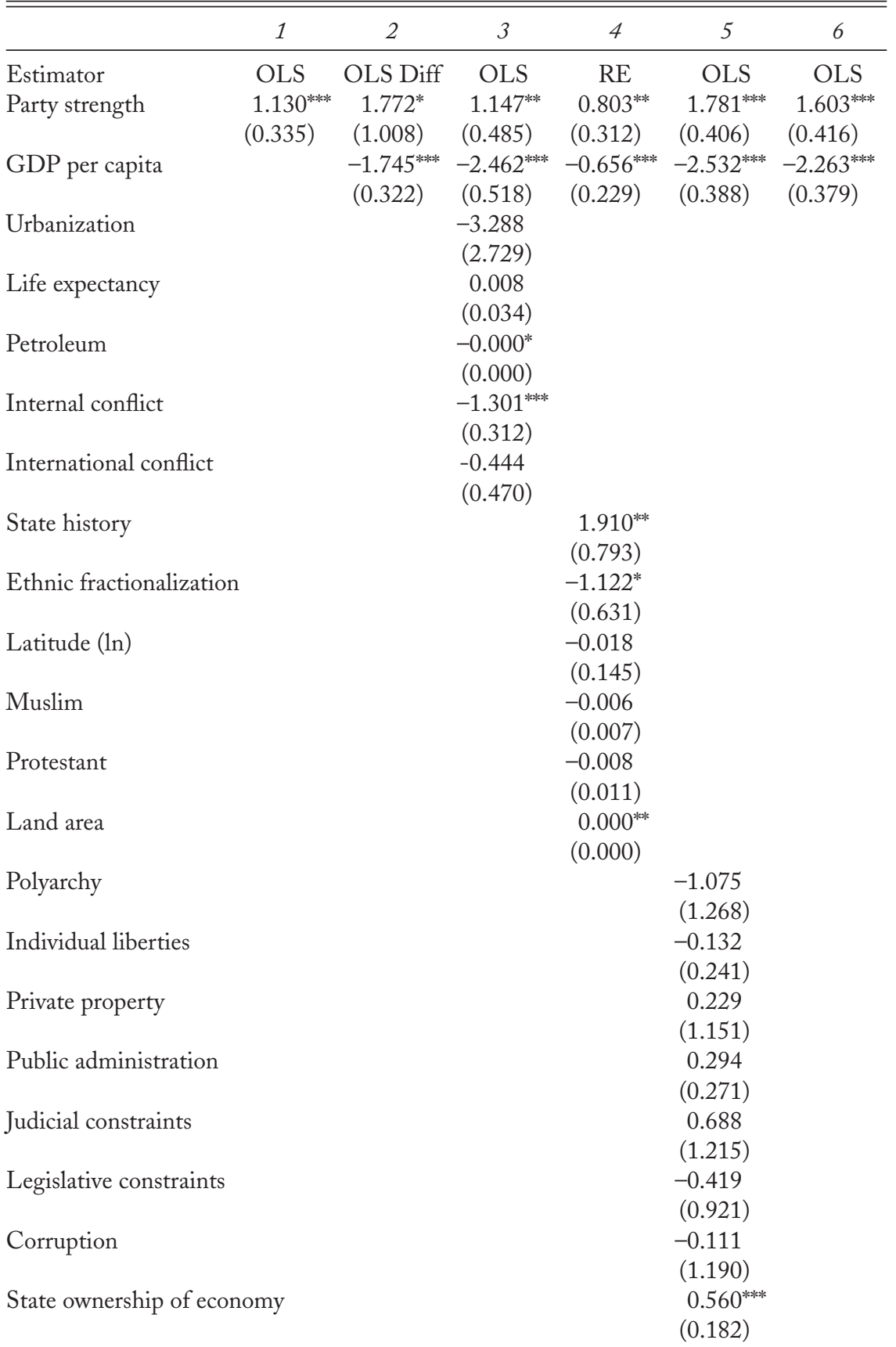


TABLE 2 (cont.)

\begin{tabular}{lcccccc}
\hline \hline & 1 & 2 & 3 & 4 & 5 & 6 \\
\hline Core civil society & & & & & -0.611 & \\
& & & & & $(1.052)$ & \\
Polity2 & & & & & & -0.011 \\
& & & & & & $(0.024)$ \\
Constant & 1.059 & $17.952^{* * *}$ & $18.753^{* * *}$ & $8.981^{* * * *}$ & $18.283^{* * * *}$ & $16.352^{* * *}$ \\
& $(0.714)$ & $(2.664)$ & $(3.855)$ & $(2.046)$ & $(3.049)$ & $(2.642)$ \\
Obs & 10179 & 10114 & 6862 & 4285 & 9556 & 8884 \\
Countries & 153 & 153 & 106 & 93 & 153 & 148 \\
Min. Years & 11 & 10 & 13 & 10 & 1 & 1 \\
Avg. Years & 66.5 & 66.1 & 64.7 & 46.1 & 62.5 & 60.0 \\
Max. Years & 110 & 109 & 107 & 49 & 110 & 110 \\
R-squared (within) & 0.101 & 0.105 & 0.116 & 0.077 & 0.123 & 0.126 \\
\hline
\end{tabular}

Standard errors clustered by country; ${ }^{*} \mathrm{p}<.10,{ }^{*} \mathrm{p}<.05,{ }^{* * * *} \mathrm{p}<.01$

${ }^{a}$ Outcome: per capita GDP growth. Unit of analysis: country year. FE: fixed effects. All right-side variables lagged by one year. Estimator: oLs (ordinary least squares), Diff (difference in differences), RE (random effects).

urbanization, life expectancy, petroleum production, and intra- and interstate armed conflict.

Model 4 adds a number of fixed covariates to the benchmark model including state history, ethnic fractionalization, percent Muslim, percent Protestant, land area, legal origin (English, French, etc.), regime type, ${ }^{103}$ and region dummies. These variables, which change little or not at all across the period of observation, replace country fixed effects in a random-effects model. Coefficient estimates for party strength are stable across all these tests and are comparable in magnitude to the benchmark.

The final tests in Table 2 focus on indices measuring various features pertaining to the quality of political institutions and overall state capacity, often highlighted as factors in long-run growth performance. ${ }^{104} \mathrm{Be}-$ cause changes in these institutional features are likely to correlate with changes in party strength, they could serve as confounders in a fixedeffect model.

Model 5 includes several indices from the V-Dem data set: polyarchy (a composite measure of electoral democracy), individual liberties (an index combining scores for seven basic civil liberties), property rights, public administration (combining indicators for the impartiality

\footnotetext{
${ }^{103}$ Following the typology from Geddes, Wright, and Frantz 2014.

${ }^{104}$ E.g., Acemoglu and Robinson 2013; Fukuyama 2011; Knack and Keefer 1995; North 1990; Rodrik, Subramanian, and Trebbi 2004.
} 
of public administration and for transparent laws and enforcement), judicial and legislative constraints on the executive, corruption, state ownership of economy, and core civil society. Model 6 includes a nonV-Dem measure of democracy, the Polity2 index from the Polity IV data set.

Surprisingly, the estimated effect of party strength on growth is stronger when additional measures of governance are included. ${ }^{105}$ Equally surprising, the other institutional measures - with the exception of state ownership of economy - are not robust predictors of growth when controlling for party strength.

The inclusion of these indices also mitigates a potential threat to inference stemming from the foreknowledge that V-Dem coders have about the left side of our causal model. Specifically, country experts may be more inclined to assign a high score to a country along some institutional parameter during a period in which a country experiences high growth. If so, the relationship in our benchmark model could be spurious, a product of coding circularity. But if coding circularity exists, we would also expect it to affect other institutional variables coded by $\mathrm{V}$ Dem or polity raters. Moreover, we would expect it to manifest itself more strongly with institutional variables that are widely assumed to be associated with economic performance, such as corruption. The fact that the main result holds even when controlling for these subjectively coded institutions alleviates concern about coding circularity.

In the supplementary material we probe deeper into the possibility that other institutional features drive the party strength/growth relationship. Table G7 displays tests in which growth is regressed against each of the variables in model 5, Table 2, independently, and results are fairly stable.

Notably, we have discussed the widely studied role of strong states in promoting economic development. Although we surmise that the effect of party strength on growth may coexist with substantial effects of having strong state institutions, we want to ensure that our results are not driven by strong states producing both strong parties and high growth.

Tables G13, G14, and G15 test three measures of state capacity. For each measure, we test various model specifications to assess robustness. The first measure, drawn from $\mathrm{V}$-Dem, gauges rigor and impartiality in public administration. The second measure is a latent measure of overall state capacity, ${ }^{106}$ providing a shorter time series. The third measure is a

\footnotetext{
${ }^{105}$ Checking whether this change is due to sample differences, the tests contained in supplementary material tables G9 and G10 suggest that this is not the case; Bizzarro et al. 2018b.

${ }^{106}$ From Hanson and Sigman 2013.
} 
time-invariant index of state history, ${ }^{107}$ also included in Table 2. These tests corroborate our theoretical expectation that both party strength and state capacity are relevant predictors of economic growth, acting independently on that outcome.

We also check the robustness of our findings to the inclusion of key constitutional features, such as parliamentarism and electoral system rules, both of which may impact party strength as well as growth, especially in democratic contexts. ${ }^{108}$ Tests displayed in tables G10 and G11 show that despite the small number of observations in these samples, party strength remains (weakly) significant. ${ }^{109}$

We turn next to the question of scope conditions. Recall that our theory is broadly framed. To probe this assumption and to alleviate concerns about influential cases or time periods, the benchmark model is replicated in a series of split-sample tests, displayed in Table 3.

We begin by excluding specific regions of the world-sub-Saharan Africa, Asia and the Pacific, Eastern Europe and the post-Soviet region, Latin America, and the Middle East and North Africa. Models 1 through 5 demonstrate that the relationship between party strength and growth persists in all of these subsample tests. Moreover, the coefficient estimates vary within a fairly narrow range (from 1.1 to 1.8 ) around the estimate from the full sample (model 1, Table 1).

Next, we divide the sample into Western countries (Western Europe, North America, Australia, New Zealand) and non-Western countries (the remainder), as shown in models 6 and 7. Results suggest a somewhat stronger relationship between party strength and growth in the West- though the estimated coefficient in the non-Western sample (model 7) is comparable to the benchmark model.

To test our supposition that the relationship of interest operates similarly across regime types, we divide the sample into democracies (model 8) and autocracies (model 9) using the binary regime-type index constructed by Carles Boix, Michael Miller, and Sebastian Rosato. ${ }^{110}$ The coefficients for party strength in both models are comparable and the $\mathrm{t}$-statistics are large, supporting our claim that the impact of party strength on growth is orthogonal to regime type. Strikingly, the coefficients for party strength, as well as those for per capita GDP in both models, are considerably higher than in our benchmark model; the

${ }^{107}$ Drawn from Bockstette, Chanda, and Putterman 2002.

${ }^{108}$ See, e.g., Knutsen 2011b; Samuels and Shugart 2010.

${ }^{109}$ This result does not hinge on whether we code mixed systems as majoritarian or exclude mixed systems. Interestingly, split-sample tests indicate that party strength is more clearly related to growth in PR systems, but we highlight that these regressions rely on few observations.

${ }^{110}$ Boix, Miller, and Rosato 2013. 


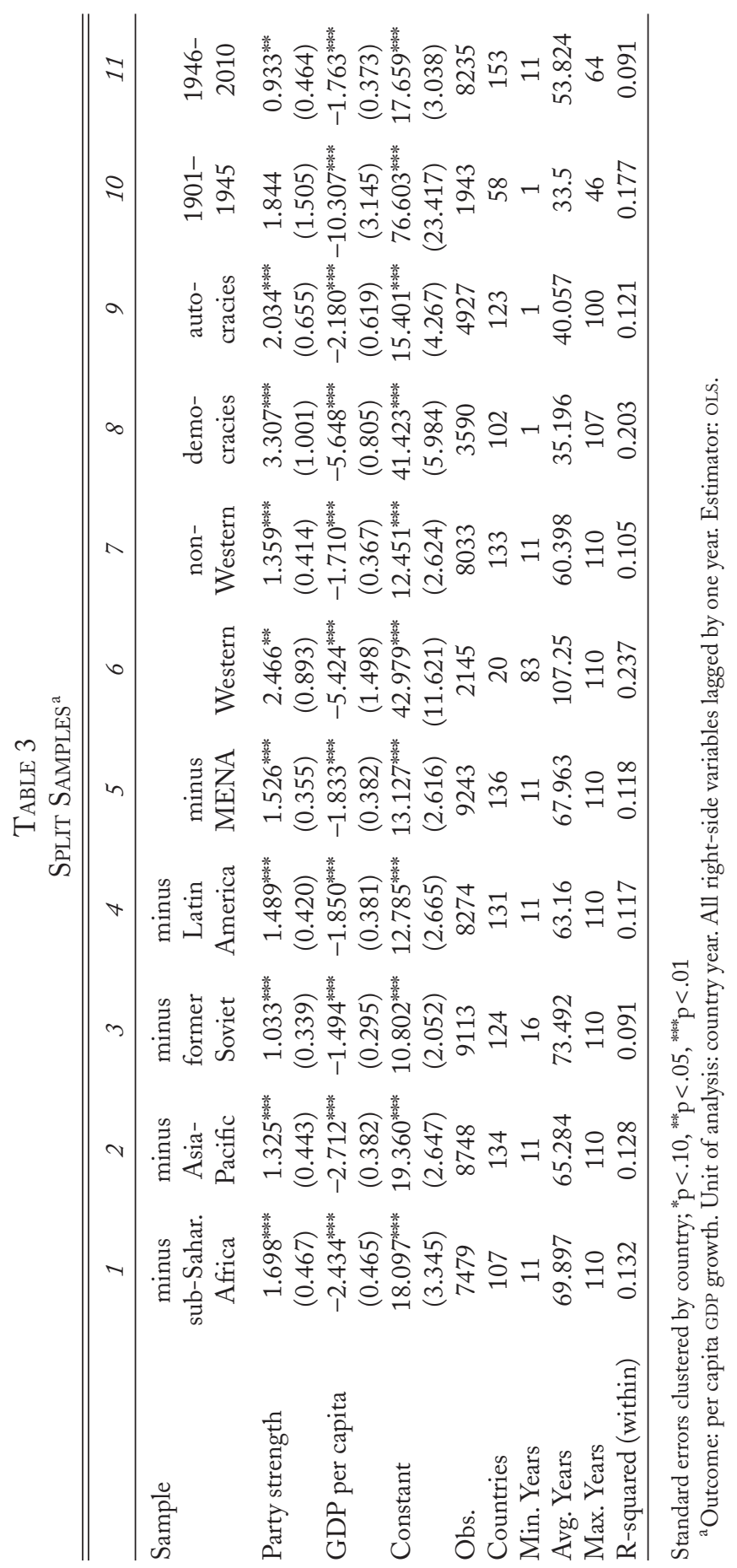


standard errors are also larger, presumably a product of reduced sample size. Party strength is also positively related to growth in long difference specifications, following Acemoglu and Johnson, ${ }^{111}$ in subsamples of both consistently democratic and autocratic countries.

To check for variation through time, we run the benchmark model across a global sample extending from 1900 to 1945 (model 10) and 1946 to 2009 (model 11). We again find fairly consistent results. Experimenting with different cutoffs, we find that the point estimate is typically somewhat higher for earlier periods, but more precisely estimated for later periods (presumably due to the larger sample). Yet the relationship between party strength and growth does not seem subject to strong period effects across the twentieth century. To more systematically assess this issue, we run our benchmark model using subsamples of observations across a moving window of thirty years - a rolling regression (1900-1929, 1901-1930, 1902-1931, etc.). Figure G1 in the supplementary material plots consistently positive coefficients, which are remarkably similar to the values observed in the benchmark model with the full sample; the only exception concerns samples covering the interwar years, where the estimated effect is substantially larger, but also imprecisely estimated.

We also test interaction models to assess the extent to which the effect of party strength on growth may be contingent on regime-type, region, and time period (see Table G8 in the supplementary material). Results are similar to those discussed above. ${ }^{112}$ Thus, although we cannot discard the possibility that party strength's effect on growth is larger in some contexts than in others, our analyses suggest that the effect is substantial in a variety of settings.

\section{Growth Stability}

In gauging the impact of economic growth on human welfare one must be concerned not only with average rates, but also with stability. A steady growth rate is preferred over an irregular one, and severe swings in economic performance usually have negative consequences. ${ }^{113}$

Our theory suggests that strong parties should foster stable economic performance. In Table 4, we provide three tests of this hypothesis. First,

\footnotetext{
${ }^{111}$ Acemoglu and Johnson 2007.

${ }^{112}$ For models that include and interact decade and regional dummies, using both fixed- and random-effects estimators, see Table G6 in the supplementary material; Bizzarro et al. 2018b. The main result is robust also in this specification.

${ }^{113}$ Rodrik 2008.
} 
TABLE 4

Growth StabiLity ${ }^{\mathrm{a}}$

\begin{tabular}{lccc}
\hline \hline & 1 & 2 & 3 \\
\hline Outcome & growth crisis & sustained growth & growth volatility \\
Measure & (growth $<0)$ & (growth $>0,5$ years) & (growth SD, 10 years) \\
Estimator & OLS & OLS & PCSE \\
Party strength & $-0.076^{* * * *}$ & $0.110^{* * * *}$ & $-0.572^{* * * *}$ \\
& $(0.026)$ & $(0.034)$ & $(0.145)$ \\
GDP per capita & $0.041^{* *}$ & $-0.104^{* * * *}$ & -0.100 \\
& $(0.018)$ & $(0.032)$ & $(0.158)$ \\
Constant & 0.191 & $0.759^{* * * *}$ & $5.015^{* * * *}$ \\
& $(0.148)$ & $(0.224)$ & $(1.244)$ \\
Obs. & 10178 & 9500 & 8655 \\
Countries & 153 & 153 & 153 \\
Min. Years & 11 & 7 & 2 \\
Avg. Years & 66.5 & 62.1 & 56.6 \\
Max. Years & 110 & 106 & 101 \\
R-squared (within) & 0.114 & 0.139 & 0.183 \\
\hline
\end{tabular}

Standard errors clustered by country; ${ }^{*} \mathrm{p}<.10,{ }^{* *} \mathrm{p}<.05,{ }^{* * * *} \mathrm{p}<.01$.

${ }^{a}$ Growth crisis: coded 1 if growth is negative. Sustained growth: coded 1 if growth is positive in five-year moving window. Growth volatility: standard deviation of growth across a ten-year moving window. Units of analysis: country year. Independent variables lagged by one time period. Estimator: OLS (ordinary least squares), PCSE (panel-corrected standard errors with panel-specific AR(1) autocorrelation).

we examine whether party strength reduces the likelihood of economic crisis, understood as an episode of negative per capita GDP growth (recoded as a dummy variable). Second, we examine whether party strength enhances the likelihood of periods of sustained growth, understood as five years of consecutive growth. Third, we examine whether party strength reduces growth volatility, understood as the standard deviation of growth performance across a ten-year period.

Results, shown in models 1-3 of Table 4, corroborate our hypothesis. Party strength is associated not only with higher growth, as shown in previous tables, but also with more stable economic performance. Elaborations of these tests are reported in the supplementary material in Appendix I, which includes a more detailed discussion of chosen measures and estimators. In it, we also present robustness tests using alternate measures of economic stability and alternate estimators (including OLS models). ${ }^{114}$

\footnotetext{
${ }^{114}$ Section $\mathrm{J}$ in the supplementary material contains results from various specifications probing measures that proxy for theoretically relevant mediating factors discussed in Section I in the supplementary material (Bizzarro et al. 2018b), and a longer discussion on the assumptions and interpre-
} 


\section{CONCLUSION}

In this article, we argue that strong parties play a critical role in fostering economic development. Our theoretical argument highlights how strong parties establish a relationship of accountability between party leaders and party members, encourage long time horizons, and enhance the party's capacity to solve coordination problems. These features enhance the probability that politicians engage in responsible economic management, provide public goods, and help to ensure political stability. This behavior, in turn, triggers investments and other productivityenhancing actions by economic actors that enhance economic growth in the short and long term.

Drawing on a novel measure of party strength from the V-Dem data set, we test this theory on data from more than 150 countries observed annually across the twentieth and twenty-first centuries. We identify a sizeable and highly significant causal effect that is robust to a variety of specifications, estimators, and samples. The effect persists in democracies and autocracies, and is fairly stable across various regions of the world and across time periods. We also explore the role of strong parties in providing growth stability.

This study contributes to two large literatures focused respectively on political parties and the institutional determinants of growth. Although previous work highlights the role of parties in improving the quality of governance, such claims are usually limited in context to democratic or authoritarian settings and generally do not pertain to distal outcomes, such as per capita GDP growth. Studies of economic development, while focused explicitly on growth, generally identify other long-run causal factors, such as geography, property rights, political constraints, state capacity, colonial origins, inequality, social capital, or human capital. In these respects, this article is novel, though it does not impugn the role of these other factors. Insofar as institutions matter, it stands to reason that different institutions may have independent effects on economic performance.

Our findings suggest several avenues for further research. First, although we provide a preliminary exploration of causal mechanisms, it will be helpful to arrive at a more precise specification of the pathways

tation of these mediation results. In line with the mechanisms suggested by our argument, we find evidence that party strength may enhance growth through improving political stability and mitigating armed conflict and through improving macroeconomic management (as proxied by reduced inflation) and through improving the provision of basic public services (as proxied by reduced infant mortality). We also find evidence that party strength enhances physical capital investment. 
that connect party strength to growth. Second, we need to know more about the possible impact of party strength on other domestic policies, such as social policies, and on international policies, such as peace or war. If party strength affects growth by changing the incentives of leaders and easing coordination problems, it stands to reason this same institutional factor may matter for other outcomes of interest. In addition, it is important to push the causal question backward. Why do strong parties develop in some countries and not in others? Are there generalizable causal factors for party strength, or is the process better conceptualized as a product of critical junctures?

\section{SuPPlEMENTARY MATERIAL}

Supplementary material for this article can be found at https://doi.org/10.1017 /S0043887117000375.

\section{REFERENCES}

Acemoglu, Daron. 2009. Introduction to Modern Economic Growth. Princeton, N.J.: Princeton University Press..

Acemoglu, Daron, and Simon Johnson. 2007. "Disease and Development: The Effect of Life Expectancy on Economic Growth." Journal of Political Economy 115, no. 6: 925-85. doi: 10.1086/529000.

Acemoglu, Daron, Simon Johnson, and James A. Robinson. 2001. "The Colonial Origins of Comparative Development: An Empirical Investigation." American Economic Revierw 91, no. 5: 1369-1401. doi: 10.1257/aer.91.5.1369.

Acemoglu, Daron, Suresh Naidu, Pascual Restrepo, and James A. Robinson. 2014. "Democracy Does Cause Growth.” NBER Working Paper No. 20004. Cambridge, Mass.: National Bureau of Economic Research. At http://www .nber.org/papers/w20004.

Acemoglu, Daron, and James A. Robinson. 2013. Why Nations Fail: The Origins of Power, Prosperity, and Poverty. New York, N.Y.: Crown Business.

Alesina, Alberto, Sule Özler, Nouriel Roubini, and Phillip Swagel. 1996. "Political Instability and Economic Growth." Journal of Economic Growth 1, no. 2: 189-211. doi: 10.1007/BF00138862.

Amsden, Alice H. 1992. Asia's Next Giant: South Korea and Late Industrialization. New York, N.Y.: Oxford University Press.

Ansell, Ben W., and David J. Samuels. 2014. Inequality and Democratization: An Elite-Competition Approach. New York, N.Y.: Cambridge University Press.

Arellano, Manuel, and Stephen Bond. 1991. "Some Tests of Specification for Panel Data: Monte Carlo Evidence and an Application to Employment Equations." Review of Economic Studies 58, no. 2: 277-97. doi: 10.2307/2297968.

Aspinall, Edward. 2014. "When Brokers Betray: Clientelism, Social Networks, and Electoral Politics in Indonesia." Critical Asian Studies 46, no. 4: 545-70. doi: 10.1080/14672715.2014.960706. 
Balisacan, Arsenio M., and Hal Hill, eds. 2003. The Philippine Economy: Development, Policies, and Challenges. Oxford, UK: Oxford University Press.

Bardhan, Pranab. 2005. "Institutions Matter, but Which Ones?" Economics of Transition 13, no. 3: 499-532. doi:10.1111/j.1468-0351.2005.00229.x.

Barro, Robert J., and Xavier Sala-i-Martin. 1990. "Economic Growth and Convergence across the United States." NBER Working Paper No. 3419. Cambridge, Mass.: National Bureau of Economic Research. At http://www.nber .org/papers/w3419.

Bernhard, Michael, Allen Hicken, Christopher Reenock, and Staffan Lindberg. 2015. "Institutional Subsystems and the Survival of Democracy: Do Political and Civil Society Matter?" Working Paper No. 4. Gothenburg, Sweden: University of Gothenburg, Varieties of Democracy Institute. At https://www .v-dem.net/media/filer_public/b2/08/b208c64e-53e1-4203-bb34-5f3adc 8674c0/v-dem_working_paper_2015_4.pdf.

Besley, Timothy, and Masayuki Kudamatsu. 2008. "Making Autocracy Work." In Elhanan Helpman, ed., Institutions and Economic Performance. Cambridge, Mass.: Harvard University Press: 452-510.

Bizzarro, Fernando, John Gerring, Carl Henrik Knutsen, Allen Hicken, Michael Bernhard, Svend-Erik Skaaning, Michael Coppedge, and Staffan I. Lindberg. 2018a. "Replication Data for: Party Strength and Economic Growth." Harvard Dataverse, V1. doi: 10.7910/DVN/GHXJYL.

— 2018b. Supplementary material for "Party Strength and Economic Growth.” At https://doi.org/10.1017/S0043887117000375.

Bizzarro, Fernando, Allen Hicken, and Darin Self. 2017. "The V-Dem Party Institutionalization Index: A New Global Indicator (1900-2015).” Gothenburg, Sweden: University of Gothenburg, Varieties of Democracy Institute. At https://www.v-dem.net/media/filer_public/00/6d/006dc36d-9497-4d53-95f8 -c117fa12c2f6/v-dem_working_paper_2017_48.pdf.

Bizzarro, Fernando, Daniel Pemstein, and Michael Coppedge. 2016. "Varieties of Democracy Data: Incorporating Measurement Error.” Manuscript. At https:// kellogg.nd.edu/sites/default/files/old_files/imce/vdem/tutorial.pdf.

Blundell, Richard, and Stephen Bond. 1998. "Initial Conditions and Moment Restrictions in Dynamic Panel Data Models." Journal of Econometrics 87, no. 1: 115-43. doi: 10.1016/S0304-4076(98)00009-8.

Bockstette, Valerie, Areendam Chanda, and Louis Putterman. 2002. "States and Markets: The Advantage of an Early Start.” Journal of Economic Growth 7, no. 4: 347-69. doi: 10.1023/A:1020827801137.

Boix, Carles, Michael K. Miller, Sebastian Rosato. 2013. "A Complete Data Set of Political Regimes, 1800-2007." Comparative Political Studies 46, no. 12: 1523-54. doi: 10.1177/0010414012463905.

Boix, Carles, and Milan W. Svolik. 2013. "The Foundations of Limited Authoritarian Government: Institutions, Commitment, and Power-Sharing in Dictatorships." Journal of Politics 75, no. 2: 300-16.

Bolt, Jutta, and Jan Luiten van Zanden. 2014. "The Maddison Project: Collaborative Research on Historical National Accounts." Economic History Review 67, no. 3: 627-51. doi: 10.1111/1468-0289.12032.

Brownlee, Jason. 2007. Authoritarianism in an Age of Democratization. New York, N.Y.: Cambridge University Press. 
Bryce, James. 1896. The American Commonwealth. New York, N.Y.: Macmillan Company.

Bueno de Mesquita, Bruce, Alastair Smith, Randolph M. Siverson, and James D. Morrow. 2003. The Logic of Political Survival. Cambridge, Mass.: MIT Press.

Carreras, Miguel. 2012. "The Rise of Outsiders in Latin America, 1980-2010.” Comparative Political Studies 45, no. 12: 1451-82. doi: 10.1177/001041401244 5753.

Chiocchetti, Paolo. 2016. "Measuring Party Strength: A New Systematic Framework Applied to the Case of German Parties, 1991-2013." German Politics 25, no. 1: 84-105. doi: 10.1080/09644008.2015.1124090.

Coppedge, Michael. 1997. Strong Parties and Lame Ducks: Presidential Partyarchy and Factionalism in Venezuela. Stanford, Calif.: Stanford University Press.

Coppedge, Michael, John Gerring, Staffan I. Lindberg, Svend-Erik Skaaning, Jan Teorell, David Altman, Michael Bernhard, M. Steven Fish, Adam Glynn, Allen Hicken, Carl Henrik Knutsen, Joshua Krusell, Anna Lührmann, Kyle L. Marquardt, Kelly McMann, Valeriya Mechkova, Moa Olin, Pamela Paxton, Daniel Pemstein, Josefine Pernes, Constanza Sanhueza Petrarca, Johannes von Römer, Laura Saxer, Brigitte Seim, Rachel Sigman, Jeffrey Staton, Natalia Stepanova, and Steven Wilson. 2017a. "V-Dem [Country-Year/CountryDate] Data set v7." Varieties of Democracy Project. At https://www.v-dem .net/en/data/data-version-7-1/.

Coppedge, Michael, John Gerring, Staffan I. Lindberg, Svend-Erik Skaaning, Jan Teorell, Joshua Krusell, Kyle L. Marquardt, Valeriya Mechkova, Daniel Pemstein, Josefine Pernes, Laura Saxer, Natalia Stepanova, Eitan Tzelgov, Yiting Wang, and Steven Wilson. 2017b. "V-Dem Methodology v7.1." Varieties of Democracy Project. At https://www.v-dem.net/media/filer_public/f2/82 /f282f504-c3c8-4fff-8277-e9fda9d54934/methodology_v71.pdf.

Croissant, Aurel, and Philip Völkel. 2012. "Party System Types and Party System Institutionalization: Comparing New Democracies in East and Southeast Asia.” Party Politics 18, no. 2: 235-65. doi: 10.1177/1354068810380096.

Cruz, Cesi, and Philip Keefer. 2015. "Political Parties, Clientelism, and Bureaucratic Reform.” Comparative Political Studies 48, no. 14: 1942-73. doi: 10.1177 /0010414015594627.

David, Paul Theodore. 1972. Party Strength in the United States, 1872-1970. Charlottesville, Va.: University of Virginia Press.

Diaz-Cayeros, Alberto, Federico Estévez, Beatriz Magaloni. 2016. The Political Logic of Poverty Relief: Electoral Strategies and Social Policy in Mexico. New York, N.Y.: Cambridge University Press.

de Dios, Emmanuel, and Paul Hutchcroft. 2003. "Political Economy: Examining Current Challenges in Historical Perspective." In Arsenio M. Balisacan and Hal Hill. eds. The Philippines Economy: Development, Policies, and Challenges. Oxford, UK: Oxford University Press.

Doner, Richard F. 2009. The Politics of Uneven Development: Thailand's Economic Growth in Comparative Perspective. New York, N.Y.: Cambridge University Press.

Evans, Peter B. 1989. "Predatory, Developmental, and Other Apparatuses: A Comparative Political Economy Perspective on the Third World State." Sociological Forum 4, no. 4: 561-87. doi: 10.1007/BF01115064. 
Evans, Peter B., and James E. Rauch. 1999. "Bureaucracy and Growth: A CrossNational Analysis of the Effects of 'Weberian' State Structures on Economic Growth.” American Sociological Review 64, no. 5: 748-65. At http://www.jstor .org/stable/2657374.

Finer, Samuel E. 2002. The Man on Horseback: The Role of the Military in Politics. New Brunswick, N.J.: Transaction Publishers.

Fjelde, Hanne. 2010. "Generals, Dictators, and Kings: Authoritarian Regimes and Civil Conflict, 1973-2004." Conflict Management and Peace Science 27, no. 3: 195-218. doi: 10.1177/0738894210366507.

Fukuyama, Francis. 2011. The Origins of Political Order: From Prehuman Times to the French Revolution. New York, N.Y.: Farrar, Straus and Giroux.

Gandhi, Jennifer. 2008. Political Institutions under Dictatorship. New York, N.Y.: Cambridge University Press.

Gates, Scott, Håvard Hegre, Håvard M. Nygård, and Håvard Strand. 2012. "Development Consequences of Armed Conflict." World Development 40, no 9: 1713-22. doi: 10.1016/j.worlddev.2012.04.031.

Geddes, Barbara. 2005. "Why Parties and Elections in Authoritarian Regimes?" Paper presented at the annual meeting of the American Political Science Association, Washington, D.C.

Geddes, Barbara, Joseph Wright, and Erica Frantz. 2014. "Autocratic Breakdown and Regime Transitions: A New Data Set.” Perspectives on Politics 12, no. 2: 313-31. doi: 10.1017/S1537592714000851.

Gehlbach, Scott, and Philip Keefer. 2011. "Investment without Democracy: Ruling-Party Institutionalization and Credible Commitment in Autocracies." Journal of Comparative Economics 39, no. 2: 123-39. doi: 10.1016/j.jce.2011.04 .002 .

. 2012. "Private Investment and the Institutionalization of Collective Action in Autocracies: Ruling Parties and Legislatures." Journal of Politics 74, no. 2: 621-35. doi: 10.1017/s0022381611001952.

Gerring, John, Phillip J. Bond, William T. Barndt, and Carola Moreno. 2005. "Democracy and Economic Growth: A Historical Perspective." World Politics 57, no. 3 (April): 323-64. doi: 10.1353/wp.2006.0002.

Gerring, John, and Strom C. Thacker. 2008. A Centripetal Theory of Democratic Governance. New York, N.Y.: Cambridge University Press.

Greene, Kenneth F. 2007. Why Dominant Parties Lose: Mexico's Democratization in Comparative Perspective. New York, N.Y.: Cambridge University Press.

Gulzar, Saad, and Benjamin J. Pasquale. 2017. "Politicians, Bureaucrats, and Development: Evidence from India." American Political Science Review 111, no. 1: 162-83. doi: 10.1017/S0003055416000502.

Hadenius, Axel, and Jan Teorell. 2007. "Pathways from Authoritarianism." Journal of Democracy 18, no. 1: 143-57. At https://www.journalofdemocracy.org/article /pathways-authoritarianism.

Haggard, Stephan, and Lydia Tiede. 2011. "The Rule of Law and Economic Growth: Where Are We?" World Development 39, no. 5: 673-85. doi: 10.1016/j .worlddev.2010.10.007.

Hankla, Charles R. 2006. "Party Strength and International Trade: A Cross-National Analysis." Comparative Political Studies 39, no. 9: 1133-56. doi: 10.1177 /0010414005281936. 
Hanson, Jonathan K., and Sigman, Rachel. 2013. Leviathan's Latent Dimensions: Measuring State Capacity for Comparative Political Research. Manuscript. At https://ssrn.com/abstract=1899933.

Hanson, Stephen E. 2010. Post-Imperial Democracies: Ideology and Party Formation in Third Republic France, Weimar Germany, and Post-Soviet Russia. New York, N.Y.: Cambridge University Press.

Hicken, Allen. 2008. "Politics of Economic Recovery in Thailand and the Philippines." In Andrew MacIntyre, T. J. Pempel, and John Ravenhill, eds., Crisis as Catalyst Asia's Dynamic Political Economy. Ithaca, N.Y.: Cornell UniversityPress: 206-30.

- 2013. "Late to the Party: The Development of Partisanship in Thailand." TRaNS: Trans-Regional and-National Studies of Southeast Asia 1, no. 2: 199-213. doi:10.1017/trn.2013.3.

- 2016. "Party Systems and the Politics of Development." In Carol Lancaster and Nicolas van de Walle, eds., Oxford Handbook on the Politics of Development. New York, N.Y.: Oxford University Press.

Hicken, Allen, Ken Kollman, and Joel W. Simmons. 2016. "Party System Nationalization and the Provision of Public Health Services." Political Science Research and Methods 4, no. 3: 573-94. doi: 10.1017/psrm.2015.41.

Hicken, Allen, and Erik Martinez Kuhonta. 2015. "Introduction: Rethinking Party System Institutionalization in Asia." In Allen Hicken and Erik Martinez Kuhonta, eds., Party System Institutionalization in Asia: Democracies, Autocracies, and the Shadows of the Past. New York, N.Y.: Cambridge University Press.

Hicken, Allen, and Joel Selway. 2012. "Forcing the Genie Back in the Bottle: Sociological Change, Institutional Reform, and Health Policy in Thailand.” Journal of East Asian Studies 12, no. 1: 57-88. doi: 10/1017/S1598240800007621.

Hicken, Allen, and Joel W. Simmons. 2008. "The Personal Vote and the Efficacy of Education Spending." American Journal of Political Science 52, no. 1: 109-24. doi: 10.1111/j.1540-5907.2007.00302.x.

Holmøy, Erling, and Kyrre Stensnes. 2008. "Will the Norwegian Pension Reform Reach Its Goals? An Integrated Micro-Macro Assessment." Discussion Paper No. 557. Oslo, Norway: Statistics Norway. At http://www.ssb.no/a/publikas joner/pdf/DP/dp557.pdf.

Honaker, James, Gary King, and Matt Blackwell. 2011. "Amelia II: A Program for Missing Data.” Journal of Statistical Software 45, no. 7: 1-47. doi: 10.18637 /jss.v045.i07.

Huntington, Samuel P. 1957. The Soldier and the State: The Theory and Politics of Civil-Military Relations. Cambridge, Mass.: Belknap Press of Harvard University Press.

-1968. Political Order in Changing Societies. New Haven, Conn.: Yale University Press.

Hutchcroft, Paul D. 1998. Booty Capitalism: The Politics of Banking in the Philippines. Ithaca, N.Y.: Cornell University Press.

. 2000. "Obstructive Corruption: The Politics of Privilege in the Philippines." In Mushtaq H. Khan and Kwame Jomo Sundaran, eds., Rents, RentSeeking, and Economic Development. Cambridge, UK: Cambridge University Press: 207-47. 
Hutchcroft, Paul D., and Joel Rocamora. 2003. "Strong Demands and Weak Institutions: The Origins and Evolution of the Democratic Deficit in the Philippines." Journal of East Asian Studies 3, no. 2: 259-92. doi:10.1017/S1598 240800001363.

Hutchison, Jane. 2001. "Crisis and Change in the Philippines.” In Garry Rodan, Kevin Hewison, and Richard Robison, eds., The Political Economy of SouthEast Asia. Conflicts, Crises, and Change. Melbourne, Australia: Oxford University Press: 42-70.

Jackson, Robert H., and Carl G. Rosberg. 1982. Personal Rule in Black Africa: Prince, Autocrat, Prophet, Tyrant. Berkeley, Calif.: University of California Press.

Keefer, Philip. 2007. "Governance and Economic Growth.” In L. Allan Winters and Shahid Yusuf, eds., Dancing with Giants: China, India, and the Global Economy. Washington, D.C.: World Bank International Bank for Reconstruction and Development/Institute of Policy Studies: 189-217.

- 2013. "Organizing for Prosperity: Collective Action, Political Parties and the Political Economy of Development." Policy Research Working Paper No. 6583. Washington, D.C.: World Bank. At http://elibrary.worldbank.org/doi /pdf/10.1596/1813-9450-6583.

Kitschelt, Herbert, and Steven I. Wilkinson. 2007. Patrons, Clients, and Policies: Patterns of Democratic Accountability and Political Competition. New York, N.Y.: Cambridge University Press.

Knack, Stephen, and Philip Keefer. 1995. "Institutions and Economic Performance: Cross-Country Tests Using Alternative Institutional Measures.” Economics E' Politics 7, no. 3: 207-27. doi: 10.1111/j.1468-0343.1995.tb00111.x.

Knutsen, Carl Henrik. 2011a. "Democracy, Dictatorship, and Protection of Property Rights." Journal of Development Studies 47, no. 1: 164-82. doi: 10.1080 /00220388.2010.506919.

- 2011b. "Which Democracies Prosper? Electoral Rules, Form of Government, and Economic Growth.” Electoral Studies 30, no. 1: 83-90. doi:10.1016/j .electstud.2010.09.006.

- 2013. Democracy, State Capacity, and Economic Growth. World Development 43, March: 1-18. doi: 10.1016/j.worlddev.2012.10.014

Kohli, Atul. 1994. "Where Do High Growth Political Economies Come From? The Japanese Lineage of Korea's 'Developmental State.”' World Development 22, no. 9: 1269-93. doi: 10.1016/0305-750X(94)90004-3.

-2004. State-Directed Development: Political Power and Industrialization in the Global Periphery. New York, N.Y.: Cambridge University Press.

Kremer, M. 1993. "The O-ring Theory of Economic Development.” Quarterly Journal of Economics 108, no. 3: 551-75. doi: 10.2307/2118405.

Kuhonta, Eric. 2011. The Institutional Imperative: The Politics of Equitable Development in Southeast Asia. Stanford, Calif.: Stanford University Press.

LeBas, Adrienne. 2011. From Protest to Parties: Party-Building and Democratization in Africa. New York, N.Y.: Oxford University Press.

Leftwich, Adrian. 1995. "Bringing Politics Back In: Towards a Model of the Developmental State.” Journal of Development Studies 31, no. 3: 400-27. doi: 10. 1080/00220389508422370.

Levine, Ross, Norman Loayza, and Thorsten Beck. 2000. "Financial Intermediation and Growth: Causality and Causes." Journal of Monetary Economics 46, no. 1: 31-77. 
Levitsky, Steven. 2003. Transforming Labor-Based Parties in Latin America: Argentine Peronism in Comparative Perspective. New York, N.Y.: Cambridge University Press.

Levitsky, Steven, James Loxton, Brandon Van Dyck, and Jorge I. Domínguez. 2016. Challenges of Party-Building in Latin America. New York, N.Y.: Cambridge University Press.

Lucas, Robert E., Jr. 1988. “On the Mechanics of Economic Development.” Journal of Monetary Economics 22, no. 1: 3-42. doi: 10.1016/0304-3932(88)90168-7.

MacIntyre, Andrew J., ed. 1994. Business and Government in Industrialising Asia. Ithaca, N.Y.: Cornell University Press.

Mackie, Jamie, and Bernardo Villegas. 1999. "The Philippines: Still an Exceptional Case?" In James Morley, ed., Driven by Growth: Political Change in the Asia-Pacific Region. Armonk, N.Y.: M. E. Sharpe: 142-60.

Magaloni, Beatriz. 2006. Voting for Autocracy: Hegemonic Party Survival and Its Demise in Mexico. New York, N.Y.: Cambridge University Press.

- 2008. "Credible Power-Sharing and the Longevity of Authoritarian Rule." Comparative Political Studies 41, no. 4-5: 715-41. doi: 10.1177/0010414007 313124.

Magaloni, Beatriz, and Ruth Kricheli. 2010. "Political Order and One-Party Rule." Annual Review of Political Science 13: 123-43. doi: 10.1146/annurev.polisci .031908.220529.

Mainwaring, Scott, Fernando Bizzarro, and Ana Petrova. 2018. "Party System Institutionalization, Decay, and Collapse." In Scott Mainwaring, ed., Party Systems in Latin America: Institutionalization, Decay, and Collapse. New York, N.Y.: Cambridge University Press.

Mainwaring, Scott, and Timothy R. Scully. 1995. Building Democratic Institutions: Party Systems in Latin America. Stanford, Calif.: Stanford University Press.

Malesky, Edmund, Regina Abrami, and Yu Zheng. 2011. "Institutions and Inequality in Single-Party Regimes: A Comparative Analysis of Vietnam and China." Comparative Politics 43, no. 4: 409-27. At http://www.jstor.org/stable/2304 0636.

Malesky, Edmund, and Paul Schuler. 2011. “The Single Party Dictator's Dilemma: Information in Elections without Opposition." Legislative Studies Quarterly 36, no. 4: 491-530. doi: 10.1111/j.1939-9162.2011.00025.x.

Mankiw, N. Gregory, David Romer, and David N. Weil. 1992. "A Contribution to the Empirics of Economic Growth." Quarterly Journal of Economics 107, no. 2: 407-37. doi: 10.2307/2118477.

Manning, Carrie. 2007. "Party-Building on the Heels of War: E1 Salvador, Bosnia, Kosovo and Mozambique." Democratization 14, no. 2: 253-72. doi: 10 $.1080 / 13510340701245777$.

McGillivray, Fiona. 1997. "Party Discipline as a Determinant of the Endogenous Formation of Tariffs." American Journal of Political Science 41, no. 2: 584-607. doi: $10.2307 / 2111778$.

Miller, Michael K. 2015. "Electoral Authoritarianism and Human Development." Comparative Political Studies 48, no. 12: 1526-26. doi: 10.1177/001041401558 2051.

Müller, Wolfgang C. 2000. "Political Parties in Parliamentary Democracies: Making Delegation and Accountability Work." European Journal of Political Research 37, no. 3: 309-33. doi: 10.1111/1475-6765.00515. 
Murphy, Kevin M., Andrei Shleifer, and Robert W. Vishny. 1989. "Industrialization and the Big Push." Journal of Political Economy 97, no. 5: 1003-26. doi:10.1086/261641.

Nelson, Richard R. 2005. Technology, Institutions, and Economic Growth. Cambridge, Mass.: Harvard University Press.

Nielson, Daniel L. 2003. "Supplying Trade Reform: Political Institutions and Liberalization in Middle-Income Presidential Democracies.” American Journal of Political Science 47, no. 3: 470-91. doi: 10.1111/1540-5907.00034.

North, Douglass C. 1990. Institutions, Institutional Change, and Economic Performance. New York, N.Y.: Cambridge University Press.

North, Douglass C., and Barry R. Weingast. 1989. "Constitutions and Commitment: The Evolution of Institutions Governing Public Choice in SeventeenthCentury England.” Journal of Economic History 49, no. 4: 803-32. At http:// www.jstor.org/stable/2122739.

Olson, Mancur. 1993. "Dictatorship, Democracy, and Development." American Political Science Review 87, no. 3: 567-76. doi: 10.2307/2938736.

Panebianco, Angelo. 1988. Political Parties: Organization and Power. New York, N.Y.: Cambridge University Press.

Pascual, C., and Lim, J. 2001. "Corruption and Weak Markets: The BW Resources Stock Market Scam.” In Public Policy 5, no. 1: University of the Philippines Center for Integrative and Development Studies: 109-29.

Pemstein, Daniel, Kyle L. Marquardt, Eitan Tzelgov, Yi-ting Wang, Joshua Krusell, and Farhad Miri. 2017. "The V-Dem Measurement Model: Latent Variable Analysis for Cross-National and Cross-Temporal Expert-Coded Data." Working Paper No. 21, 2nd ed. Gothenberg, Sweden: University of Gothenburg, Varieties of Democracy Institute. doi: 10.2139/ssrn.2704787.

Pemstein, Daniel, Stephen A. Meserve, and James Melton. 2010. "Democratic Compromise: A Latent Variable Analysis of Ten Measures of Regime Type.” Political Analysis 18, no. 4: 426-49. doi: 10.1093/pan/mpq020.

Persson, Torsten, and Guido Tabellini. 2003. The Economic Effects of Constitutions. Cambridge, Mass.: MIT Press.

Pitcher, M. Anne. 2012. Party Politics and Economic Reform in Africa's Democracies. New York, N.Y.: Cambridge University Press.

Powell, Eleanor Neff, and Joshua A. Tucker. 2014. "Revisiting Electoral Volatility in Post-Communist Countries: New Data, New Results, and New Approaches." British Journal of Political Science 44, no. 1: 123-47. doi: 10.1017/S000712341 2000531.

Quimpo, Nathan G. 2005. "Review: Oligarchic Patrimonialism, Bossism, Electoral Clientelism, and Contested Democracy in the Philippines." Comparative Politics 37, no. 2: 229-50. doi:10.2307/20072884.

Randall, Vicky, and Lars Svåsand. 2002. "Party Institutionalization in New Democracies." Party Politics 8, no. 1: 5-29. doi:10.1177/1354068802008001001.

Ranney, Austin. 1954. The Doctrine of Responsible Party Government, Its Origin and Present State. Urbana, Ill.: University of Illinois Press.

Rodrik, Dani. 1991. "Policy Uncertainty and Private Investment in Developing Countries." Journal of Development Economics 36, no. 2: 229-42. doi: 10.1016 /0304-3878(91)90034-S.

- 2007. One Economics, Many Recipes: Globalization, Institutions, and Economic Growth. Princeton, N.J.: Princeton University Press. 
Rodrik, Dani, Arvind Subramanian, and Francesco Trebbi. 2004. "Institutions Rule: The Primacy of Institutions over Geography and Integration in Economic Development." Journal of Economic Growth 9, no. 2: 131-65. doi:10.1023 /B:JOEG.0000031425.72248.85.

Rokkan, Stein, and Seymour Martin Lipset. 1967. "Cleavage Structures, Party Systems, and Voter Alignments : An Introduction.” In Seymour Martin Lipset and Stein Rokkan, eds., Party Systems and Voter Alignments: Cross-National Perspectives. New York, N.Y.: Free Press: 1-64.

Romer, Paul. 1993. "Idea Gaps and Object Gaps in Economic Development." Journal of Monetary Economics 32, no. 3: 543-73. doi: 10.1016/0304-3932 (93)90029-F.

Roodman, David. 2009. "A Note on the Theme of too Many Instruments." $O x-$ ford Bulletin of Economics and Statistics 71, no. 1: 135-58. doi: 10.1111/j.1468 -0084.2008.00542.x.

Samuels, David J., and Matthew S. Shugart. 2010. Presidents, Parties, and Prime Ministers: How the Separation of Powers Affects Party Organization and Behavior. New York, N.Y.: Cambridge University Press.

Simmons, Joel W. 2016. The Politics of Technological Progress: Parties, Time Horizons, and Long-Term Economic Development. New York, N.Y.: Cambridge University Press.

Simmons, Joel W., Allen Hicken, Ken Kollman, and Irfan Nooruddin. 2017. "Party System Structure and Its Consequences for Foreign Direct Investment." Party Politics. doi: 10.1177/1354068816644762.

Solow, Robert M. 1956. "A Contribution to the Theory of Economic Growth." Quarterly Journal of Economics 70, no. 1: 65-94. At http://www.jstor.org/stable /1884513.

Stokes, Susan. 1999. "Political Parties and Democracy." Annual Review of Political Science, 2: 243-67. doi: 10.1146/annurev.polisci.2.1.243.

Svolik, Milan W. 2012. The Politics of Authoritarian Rule. New York, N.Y.: Cambridge University Press.

Tavits, Margit. 2012. "Organizing for Success: Party Organizational Strength and Electoral Performance in Postcommunist Europe." Journal of Politics 74, no. 1: 83-97. doi: 10.1017/s0022381611001198.

Tommasi, Mariano. 2006. “The Institutional Foundations of Public Policy.” Economia 6, no. 2: 1-36. doi: 10.1353/eco.2006.0022.

Ufen, Andreas. 2012. "Party Systems, Critical Junctures, and Cleavages in Southeast Asia." Asian Survey 52, no. 3: 441-64. doi: 10.1525/as.2012.52.3.441.

Wade, Robert. 1990. Governing the Market: Economic Theory and the Role of Government in East Asian Industrialization. Princeton, N.J.: Princeton University Press.

Well, David N. 2007. "Accounting for the Effect Of Health on Economic Growth." Quarterly Journal of Economics 122, no. 3: 1265-1306. doi: 10.1162/qjec.122.3 .1265 .

Weyland, Kurt. 2008. “Toward a New Theory of Institutional Change." World Politics 60, no. 2 (January): 281-314. doi: 10.1353/wp.0.0013.

Wilson, Woodrow. [1908] 2001. Constitutional Government in the United States. New Brunswick, N.J.: Transaction Publishers.

Wimmer, Andreas. 2013. Ethnic Boundary Making: Institutions, Power, Networks. New York, N.Y.: Oxford University Press. 
Woo-Cumings, Meredith. 1999. The Developmental State. Ithaca, N.Y.: Cornell University Press.

Wright, Joseph. 2008. “To Invest or Insure? How Authoritarian Time Horizons Impact Foreign Aid Effectiveness.” Comparative Political Studies 41, no. 7: 9711000. doi: 10.1177/0010414007308538. 